Article

\title{
Israelite Temples: Where Was Israelite Cult Not Practiced, and Why
}

\author{
Avraham Faust 1
}

The Department of General History, Bar-Ilan University, Ramat Gan 5290002, Israel; avraham.faust@biu.ac.il

Received: 7 January 2019; Accepted: 7 February 2019; Published: 12 February 2019

\begin{abstract}
Most scholars in the late 20th and early 21st century believed that cultic activity in the kingdoms of Israel and Judah was practiced in various temples that were scattered throughout the kingdoms. Still, a detailed study of the archaeological evidence on Israelite cult reveals that Israelite cultic buildings were extremely rare, both in absolute terms and when compared to other ancient Near Eastern societies, suggesting that cultic activity in temples was the exception rather than the norm and that typical Israelite cult was practiced in the household and in other, non-temple settings. Hence, the evidence suggests that rather than viewing temples, like the one in Arad, as exemplifying typical cultic activity, they should be viewed as exceptions that require a special explanation. The first part of the article develops and updates the suggestion, first raised about ten years ago, that Israelite temples were indeed extremely rare. Given the ancient Near Eastern context, however, such practices seems to be exceptional, and the second part of the article will therefore explain why was such a unique pattern not identified in the past, and will suggest a possible explanation as to how was such an outstanding practice developed and adopted.
\end{abstract}

Keywords: Israelite religion; temples; ancient Israel; cultic buildings; shrines; sanctuaries; biblical archaeology; egalitarian ethos

\section{Introduction}

Modern scholarship seems to have been fascinated by Israelite religion(s), and numerous attempts were made to reconstruct ancient Israelite cult. Initially, research focused on the interpretation supplied by the various texts, but as the archaeological evidence gradually accumulated, the material record came to play a major role in these reconstructions (e.g., Alpert Nakhai 2001, pp. 8-16; Zevit 2001, pp. 1-80; see also Hess 2007, pp. 43-80). While various questions surrounding Israelite religion(s) were left undecided, a consensus had been gradually established regarding the nature of Israelite cult practices, and especially on their spatial dimension. According to this consensus, Israelite cult was practiced in temples or shrines, i.e., houses built for cultic purposes in general and to house a deity in particular, and until Josiah's reforms of the late seventh century BCE such structures existed in every Israelite city, town, and village (e.g., Holladay 1987; Zevit 2001; Schmitt 2014, and many more references below). While this consensus was based on a possible reading of the biblical data, it contradicted the archaeological information available, and a few years ago I challenged this consensus (Faust 2010), and demonstrated that Iron Age Israelite temples were a rare phenomenon, and that cult was usually practiced in more simple settings, and not in buildings erected especially for this purpose.

While this view was adopted by some (below), other scholars still repeat the older maxim (e.g., Schmitt 2014; Geller 2016, p. 312, and more below), and in this article, which is part of a general issue on Archaeology and Israelite Religion, I would like to update the main arguments raised in my original paper, and then to advance one step further and to offer a possible explanation for the Israelite practice 
of preferring simpler cultic settings, in contrast to most other ancient Near Eastern societies in which temples were common. ${ }^{1}$

\section{Preliminary Notes on the Definition and Identification of Cultic Buildings}

Before beginning the archaeological survey, I would like to briefly comment on the terminology used in reference to cultic buildings and on the mere identification of buildings as cultic in the first place.

\subsection{Cultic Buildings, Temples, Shrines, and Sanctuaries}

In the following I use the term "cultic building" in a comprehensive manner, and take it to refer to any structure that was built specifically for religious purposes.

Notably, scholars used various terminologies to describe cultic buildings and activities. Examples include Zevit (2001, pp. 123-24), which referred (among other terms) to "cult complex," "cult center," "temple," "temple complex," and "shrine", Dever's (e.g., Dever 2005, pp. 111, 135, 167) discussion of "local shrines," "public open-air sanctuaries," and "monumental temples", and Schmitt's (2014, partial list) "neighborhood shrine", "village shrine", "city temple", "regional sanctuary", and "supra-regional sanctuary" (see also Holladay 1987, and see especially 282, n. 1; Zwickel 1994, p. 9; Hess 2007, pp. 39, 312-314). While a sort of hierarchy seems to be inherent in all of these studies (and will be discussed below), and although most do have an internal consistency in their use of the various terms, there is clearly no systematic terminology across studies.

For our purposes, therefore, any building that was used specifically for cultic activities (see below, Section 2.2) will be included within the broad definition of a cultic building adopted here. Although the distinction between the various possible sub-types of cultic structures is not important for our purposes-and is not used in any consistent way throughout scholarship in any case ${ }^{2}$ - for clarity I will use either the term "cultic structures" (or "buildings") or "temples" (unless when quoting others).

It should also be noted that this paper will not systematically discuss expressions of religion within the household or finds that are interpreted as small cultic corners within buildings (see for example (Albertz and Schmitt 2012); and various papers in (Albertz et al. 2014), and references, and a few examples at the beginning of Section 5). Nor will I try to identify the biblical terms of those buildings (e.g., Smith 2002; Alpert Nakhai 2001; Zevit 2001; Haran 1981).

\subsection{Identifying Cultic Buildings}

Identifying cult in archaeology is notoriously difficult (cf., Flannery 1976, pp. 329-33). Various scholars, however, have offered explicit methods to overcome the difficulties of interpreting archaeological finds as indicating cult. The most famous and influential study on the identification of cultic sites is Renfrew's (1985) study of the sanctuary at Phylakopi (see also Renfrew 1994; Renfrew and Bahn 2012, pp. 403-8; Levy 2006). Renfrew examined a number of traits which he viewed as indicative of cult, relating to settings, architecture and finds, for example, a setting or architecture that focuses attention or creates a boundary between this world and another one, or that exhibits evidence of participation and offerings to a deity.

Since in this article I do not intend to review and examine each and every cultic building identified in the past, it is important to note that some previous scholarship has explicitly attempted to follow

1 Identifying sites as Israelites is not always straightforward, and various criteria were offered over the years (e.g., Dever 2003; Bloch-Smith 2003; Faust 2006a, and references). While no consensus had been reached, during the Iron II, which is the focus of this paper, the questionable sites are fewer and, moreover, there is usually an agreement whether a certain temple was Israelite or not. Moreover, at this time there seems to have been an intended policy in Israel and Judah, expressed for example in the fate of the temples in sites like Megiddo, Tel Qasile, and others (discussed in Section 5.3), allowing us to examine the situation in these kingdoms at large.

2 This can be exemplified by the treatment of Arad. As we will see below (Section 3.2 for example) not only do different scholars use different terms to describe this structure, but sometimes the same scholar used different terms interchangeably. 
Renfrew's criteria, and this is especially true for some of the studies which were used to compile the "lists" of cultic buildings referred to below (e.g., Zevit 2001, pp. 82-83; Alpert Nakhai 2001, pp. 35-36; Hess 2007, pp. 37-39; Schmitt 2014, and others). Moreover, since the phenomenon addressed in this paper is very striking, little subtleties are not important, and unless the entire scholarly literature is completely useless, the pattern identified is extreme and requires an explanation. Thus, as problematic as some past studies are, it is clear that many of the buildings, at least, have enough traits to qualify them as "cultic." Finally, the same (whether good, or loosely defined) criteria were applied to all structures discussed in this article, including those of the Bronze Age and the Iron Age, and any obvious differences in their distribution would therefore require an explanation.

In light of the above, I would like to suggest that the patterns that will be discussed below regarding the distribution and frequency of cultic buildings are valid, and are not a result of the application of different criteria to different societies or eras, or of inappropriate methods of identifying cultic buildings. Hence, despite the difficulties inherent in past scholarship, the existing "database" of cultic structures is valid for comparative purposes and for identifying patterns in the distribution, usage, and even existence of such structures. Thus, different patterns are significant and meaningful, and are clearly a result of past behavior and not of biased data collection or from differences in interpretation.

\section{Israelite Places of Worship: The Consensus}

The earliest attempts to study Israelite religion and to identify cultic buildings or temples on the basis of the archaeological finds were eclectic and derived from incidental finds (see, e.g., the assessment of Wright 1978, p. 149). Following the accumulation of archaeological discoveries of cultic buildings and mainly religious items, however, and in light of critical analysis of the biblical information on Israelite religion(s), many scholars have attempted to systematically reconstruct the location and manner in which Israelite religion(s) was practiced. As far as cultic buildings were concerned, there was a growing consensus regarding their place in the social landscape of Israelite Iron Age society, and in the late 20th and early 21st century it was agreed that there were various loci of cult, from the individual household, through villages, urban and regional temples, to even more central temples in the national capitals.

\subsection{Typology of Israelite Cultic Buildings: The Emerging Consensus}

We shall begin our survey with Holladay's (1987) highly influential article, "Religion in Israel and Judah under the Monarchy: An Explicitly Archaeological Approach." Holladay identified various loci of cult, and created a typology of those buildings and spaces. He concluded which type of cult was typical of what setting (urban, regional, etc.) based on the characteristics of the structures he identified, and then extrapolated from these finds to the reality in Israel and Judah at large. He distinguished between "established" regional shrines and "state" temples on the one hand, and "non-conformist" shrines on the other. The term "non-conformist" shrine refers to buildings in which the cult practiced deviated from the state-sponsored religion. Holladay's "typology" of cultic buildings suggests that the "established worship" was practiced at the town and the national level, as well as at the neighborhood level (Holladay 1987, pp. 267-68).

Other scholars followed, and although the typologies are not identical, the concept of central, regional, and local cultic centers at several levels is widely accepted. Thus, Richard Hess (2007, pp. 297-314) followed Holladay's classification, at least in its general outlines, he refers to the existence of "local shrines" (p. 312), concluding that "[D]uring the later divided monarchy [eighth to sixth centuries BC] the high places continued as state-sponsored religious centers, while cult centers appeared at village sites, along trade routes, and in alternative nonconformist contexts" (p. 314). William Dever also viewed the evidence as indicative of a similar reality, and concluded that different temples were built in many locales (e.g., Dever 2005, p. 174, but see Dever 2017, and more below). Ziony Zevit (2001), in what is perhaps one of the most detailed attempt to reconstruct Israelite religions, 
scrutinized the archaeological (and non-archaeological) evidence, referring to various temples and cultic buildings, and also concluded that "the religion was practiced differently at home, village, sanctuary, urban temple, and extra-urban sanctuary" (2001, p. 265). Rudiger Schmitt's (2014) recent typology is among the most detailed, and included, among other types or locales, also "neighborhood shrine", "village shrine", "city temple", "regional sanctuary", and "supra-regional sanctuary." And Oded Borowski (2003, p. 54), in describing the daily life in biblical Israel, also wrote, "[ . . ] it is safe to assume that every city and town had a cult center or a shrine" (see also p. 24). A reality in which cultic buildings are found throughout the landscape is also depicted by Beth Alpert Nakhai (2001, but see below) and S.A. Geller (2016, p. 312).

Many biblical scholars who discussed the cultic changes following the religious reforms of the late Iron Age also noted that local temples were prevalent before those reforms. Hence Hagedorn (2005, p. 204) refers to "(A)ll the local shrines which have previously been centers [ ... ]" Vogt (2006, pp. 44, 46) also speaks about the "local sanctuaries" that existed until the time of Josiah (see also (Albertz 1994, pp. 128, 206); for the multiplicity of such buildings, (see also Smith 2002, p. 161; McNutt 1999, pp. 176-78)).

Common to these studies and typologies is the conclusion that the Israelites built temples or cultic buildings in almost every locale, and that beyond the household cult, there were cultic structures in neighborhoods, villages, towns, and there were even regional cultic centers, and central temples in the national capitals. The following quote, regarding "the relationship between local and central sanctuaries," reflects the consensus that "[ ... ] during the whole monarchical period [until the time of Josiah. A.F.] both existed side by side" (Kessler 2008, p. 89). ${ }^{3}$

\subsection{The Logic Behind the Typology}

The above-mentioned studies meticulously studied the available archaeological evidence that could be, directly and indirectly, related to Israelite religion and cult. These scholars looked at every possible clue, in order to reconstruct every possible form of religious practice, and then extrapolated from the available information in order to understand Israelite religion(s) at large. All studies explicitly or implicitly agree that the fragmentary data uncovered is representative of a larger whole. William Dever (2005, pp. 170-75), for example, after discussing the temple at Arad, wrote, "(A)ll things considered, there is no reason to suppose that the Arad temple is unique or even exceptional. Rather it appears to be an example of what was probably a widespread phenomenon-local temples" (p. 175). Hess (2007, p. 303), in a similar vein, suggested that "[T]he sanctuary at Arad probably represents a regional center" (see also Hess 2007, p. 312), and Albertz (1994, p. 128) viewed it as a "regular temple complex," and an example of "provincial sanctuaries" (see also Geller 2016, p. 332).

While these studies are exemplary in their detailed analysis of the archaeological evidence and in their interdisciplinary approach, in which the archaeological information is interpreted in light of the data available from a critical analysis of the textual sources, my 2010 article aimed to show that they are wrong, and what they viewed as "examples" are in reality exceptions.

The next sections, therefore, aim to show that a more archaeologically contextual approach to the available data indicates that the evidence used for extrapolation and which served as the basis for reconstructing Israelite cult places is the exception, rather than the rule. The emerging picture, therefore, is not representative; by multiplying the exceptions, we do not get a picture of the whole, but rather a distorted image, requiring a new approach to Israelite religion.

3 Many scholars were of course aware of the fact that not all the structures were temples or buildings erected solely for cultic purpose (see below). Still they discussed the finds as part of a spectrum, assuming the existence of many such structures, and subsequently did not identify their rarity (and see more below). 


\section{The Context: Non-Israelite Temples in the Bronze and Iron Ages}

Below we will review the scarce evidence for cultic buildings in Iron II Israel and Judah, but in order to assess this data, I would first like to put it in perspective, and will therefore briefly examine the evidence from non-Israelite cult places. Reviewing the reality in other cultures of the Bronze and Iron Age Levant (cf., Greener, Steiner, Ben-Shlomo, and Tyson, all in this issue) will give us a background against which to examine and compare the situation in Israel and Judah.

Temples are ubiquitous in Bronze Age sites (e.g., Greener, this issue; see also Bunimovitz 2019). While a comprehensive discussion is beyond the scope of this article, the next section will briefly discuss a few periodical or topical case studies.

\subsection{Late Bronze Age Temples}

Although Late Bronze Age strata were unearthed at quite a few sites, the exposure of those levels is usually limited. This limited exposure is a result of a combination of factors, including the demographic decline which characterized the period and the fact that many sites either did not have Late Bronze Age occupation whatsoever, or that occupation from this period was relatively limited in scope (Gonen 1992b, pp. 216-17; Bunimovitz 1995, pp. 321-24; 2019; see also Greener, in this issue, and more below), as well as the fact that in most instances the Late Bronze layers were deep below the mound's surface, and hence only limited exposure is possible. The number of Late Bronze Age dwellings that were excavated, for example, is limited (e.g., Gonen 1992b, p. 221), and this is of course a result of this limited exposure (more below). Still, despite the limited archaeological exposure, more than 20 Late Bronze Age temples were unearthed over the years throughout the country (for a general treatment, see Alpert Nakhai 2001, pp. 119-60; Hess 2007, pp. 125-40; Gonen 1992b, pp. 222-32; Mazar 1992a, pp. 169-83; Ottosson 1980; Wright 1985, pp. 218-23; Bunimovitz 2019; see also Greener, this issue). A selective list of temples includes Shechem, Hazor (apparently five temples), Megiddo, Lachish (at least two temples), Tel Mevorakh, Beth Shean, Timnah, Amman airport, Tel Kitan, Pella, Tel Nami, and probably also Tell Abu Hawam, Tell Abu Al-Kharaz, Tell Deir 'Alla, Tell Safut, Kh. Umm ad-Dananir, and Shiloh. In addition, Nahariya, Tel Mor, Gezer, and perhaps even Mt. Gerizim (if they are dated to the early phase of the Late Bronze Age) might also be included in the list. ${ }^{4}$ A recent find from Tall el-'Umayri (Herr and Clark 2009, pp. 76-81) might supplement the list of Late Bronze Age temples.

The evidence, therefore, clearly shows that during the Late Bronze Age temples were common. There was apparently at least one temple in each settlement, including relatively small settlements, and in many cases there was even more than one such building at a settlement. Furthermore, quite a few temples were unearthed outside settlements (e.g., the Fosse Temple at Lachish and the Amman airport temple), providing additional evidence of the wide distribution of temples in this era.

\subsection{Bronze Age Rural Temples}

Due to the demographic decline of the Late Bronze Age, no examples of Late Bronze Age villages have been excavated to an extent that allows for any social analysis. However, the data from Middle Bronze Age villages are quite illustrative.

Six Middle Bronze Age villages were excavated or surveyed to an extent that allows some reconstruction of settlement planning and community organization, and they were discussed in detail

4 This is a partial list composed mainly of sites mentioned by Gonen (1992b, pp. 222-32), and Alpert Nakhai (2001, pp. 119-60), and excludes some sites in which no architectural remains (or other sufficient evidence) were unearthed, e.g., Aphek, Ashkelon, Ashdod, and even Jaffa, as well as the structure north of Jerusalem. I would like to note that Mazar (1992a, pp. 169-83) was more critical, rejecting the identification of the some of the above-mentioned sites as temples, but even he (in an article originally published in Hebrew in 1987) identified more than 10 such buildings. Furthermore, since Mazar did not discuss all the relevant sites (e.g., Pella), and as a few sites were discovered only after he published his paper, it is clear that even the most critical "counting" will end up with at least 15 Late Bronze Age temples. 
in an attempt to reconstruct the communities that inhabited them (Faust 2005). The sites are Tell el-Hayyat (Falconer 1994, 1995), Tel Kitan (Eisenberg 1976, 1993b), Givat Sharet (near Beth-Shemesh) (Bahat 1975, 1993), Nahal Rephaim (Eisenberg 1993a), Manahat (Edelstein 1993), and probably Kfar Rupin (Gophna 1979). Interestingly, in all six sites, temples were unearthed. Sometimes the temples were large and dominated the settlement (Tell el-Hayyat and Tel Kitan), while in others the temples were relatively small (Nahal Rephaim, Manahat, and Givat Sharet). Still, despite differences between the sites, the existence of temples is characteristic, and in most cases the identification of the structures as temples seems well established. Clearly, temples are a typical feature of Middle Bronze Age villages.

This indicates that in the Bronze Age, temples were prevalent also in rural settings, and that there was probably a temple or cultic building in every Canaanite village (Faust 2005).

\subsection{Iron Age Temples outside the Kingdoms of Israel and Judah}

As part of the context in which we will evaluate the evidence from Israel and Judah, it is also worthwhile to examine the situation in other Iron Age polities and regions, outside the kingdoms of Israel and Judah.

Although the polities surrounding Israel and Judah were excavated to a much more limited extent than the latter, temples are a relatively frequent find in those regions. In Philistia (i.e., the Philistines cities and their periphery, including, probably, Canaanite settlements; see also Ben Shlomo in this issue), for example, series of Iron Age temples were found at Tel Qasile (Mazar 1980), Ekron/Miqne (Dothan 2003; Gitin 2003), and another one was unearthed at Nahal Patish (Nahshoni 2009a; 2009b). Recently, a temple was also reported at Tell es-Safi/Gath (see, e.g., Dagan et al. 2018). It is likely that a temple existed also in Yavneh, but since only the favissa was excavated, and not the actual structure, we cannot discuss it here (Kletter et al. 2010, 2013, regardless of the ethnicity of the inhabitants). ${ }^{5}$ Temples therefore seem to be a typical feature in sites in Philistia and its surroundings. Notably, Ekron, and Gath are the only sites of the above-mentioned four sites that existed in the Iron II, and are therefore the only ones which yielded also Iron II temples (Iron I temples were unearthed in three of the sites).

Although excavations in Moab are extremely limited, a cultic building was recently found at Khirbat al-Mudayna (Daviau and Steiner 2000), and another at Ataruz (Ji 2012). Another late Iron Age temple was discovered in Tell Damiya (Petit and Kafafi 2016), whose population was most likely Canaanite, and another in Rujm al Kursi in Ammon (for a recent overview, see Steiner, Tyson, in this issue).

Cultic structures were also found outside settlements, such as at Wadi Thamad site 13 in Moab (Daviau 2006), at Kh. Qitmit in the Negev (Beit Arieh 1991, 1995) and also just outside the fort of 'En Hazeva in the Aravah (Cohen and Yisrael 1995, pp. 224-28). Whether those structures should be associated with the Edomites (e.g., Beit Arieh 1991, 1995; for Qitmit) or any other group is of less importance (we tend to associate the phenomenon with the Arabian trade), and it is clear that the relevant group(s) in the southern parts of Israel and Jordan built special structures for cultic purposes.

Temples are also known in the Iron Age polities to the north of Israel and Judah. Despite the limited exposure, Iron II temples were unearthed in various sites in the Aramean states to the north, e.g., at Tell Tayinat, 'Ain Dara, Aleppo, and Hama (Akkermans and Schwartz 2003, pp. 370-75, and references). The same is true for the Phoenician cities-while excavations are extremely limited in number and scope, Iron Age Phoenician cultic buildings were exposed at Sarepta, Tell Sukas, Tell Arqa, and probably at Kition (e.g., Markoe 2000, pp. 125-29). ${ }^{6}$

5 Some scholars identified a temple also at Ashdod (e.g., Wright 1985, p. 224; Dothan 1993, p. 100; Alpert Nakhai 2001, p. 197). Still, it is likely this was only a cult room, part of a larger building (Mazar 1992a, p. 186), and in order to err at the side of caution, it will not be discussed here.

6 For a longer list of suggested non-Israelite temples, see (Alpert Nakhai 2001, p. 197, note 26), but the cultic nature of some is not certain. 
Although most of these regions were only sparsely excavated when compared to the situation in the kingdoms of Israel and Judah, the finds there include many temples, which seem to be a common feature there.

\section{Temples in Iron II Israel and Judah}

Despite the large number of excavations of Iron Age II levels in Israel and Judah, and the large overall exposure of many sites, and notwithstanding the great academic interest in Israelite religion, hardly any temples or buildings devoted to cultic purposes were unearthed in the kingdoms of Israel and Judah. One can scrutinize the list of cultic structures supplied by various scholars, but to no avail. Most of the Iron II cult places are caves or cultic corners or rooms within structures (and the mere cultic nature of many is doubted). Thus, the finds in Lachish (Aharoni 1975), Megiddo (Zevit 2001, pp. 219-31 and references), Tell el-Farah (N) (Zevit 2001, pp. 238-41 and references), and more, are just cultic rooms or corners, i.e., rooms (or even parts thereof) that were used for cultic purposes, each located within a larger, non-religion complex. These are clearly not temples, and while they were used in the past to show that cult was widespread (by scholars who accepted the "consensus", see above), there was never real justification to call them temples or cultic buildings.

The only "real", secure temple excavated in the two polities is the one at Arad (Aharoni 1993; Herzog 1997, and references; Figure 1), and it appears that another one was discovered recently in Moza (e.g., Kisilevitz 2015). The complex at Dan might also be included (Biran 1994, pp. 159-233; Figure 2), although the identification of the latter is probably dependent on the biblical text.

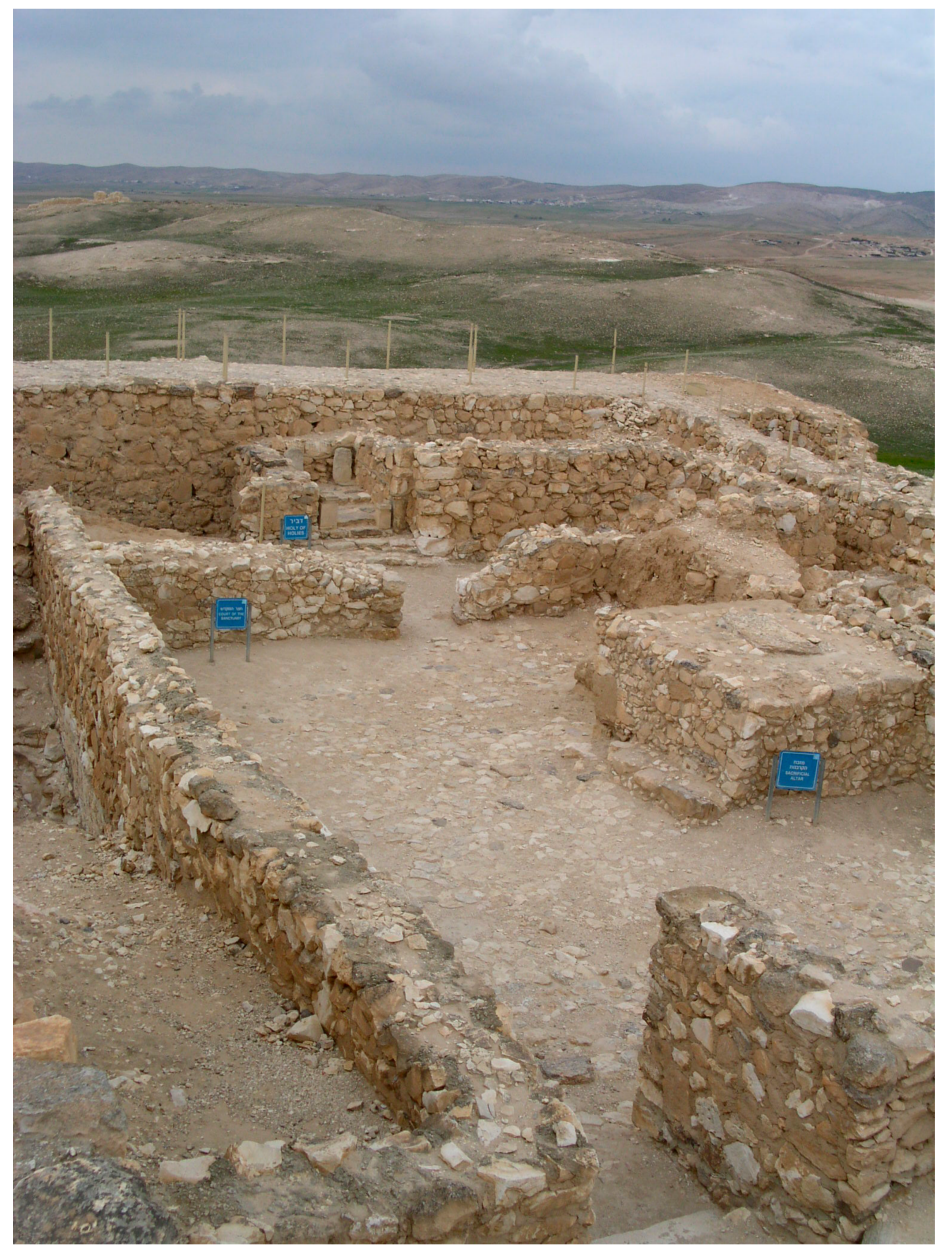

Figure 1. A photograph of the temple at Arad, after its reconstruction (photographed by the author). 


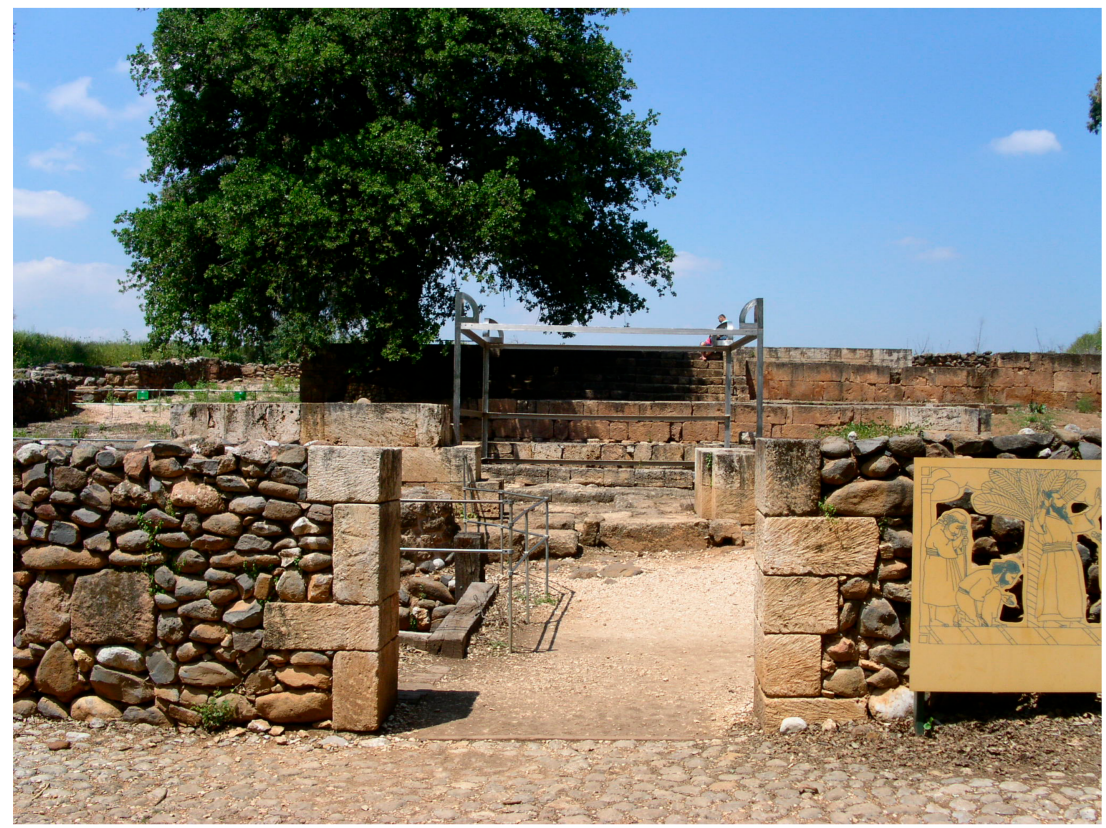

Figure 2. A photograph of the Tel Dan (reconstructed) cultic complex, with the platform at the background (photographed by the author).

The scarcity of finds is well known. Amihai Mazar (1992a), in an article on the temples of the Bronze and Iron Ages, devotes a lengthy discussion to the many temples of the second millennium BCE (pp. 161-83), and then notes the paucity of evidence for temples in the Iron II (p. 183): “(W)hereas finds from the Late Bronze Age are abundant, only a small number of sacred structures from the Iron Age II (tenth-sixth centuries B.C.) have been uncovered in Israel. These buildings are diversified in form and each of them is problematic" (p. 183; emphasis added). The only two examples of excavated Iron Age II temples cited by Mazar (published before the recent excavations in Moza) are indeed the temple at Arad and the complex at Dan (Mazar 1992a, pp. 184-86; see also Niditch 1997, p. 19).

Other scholars, moreover, include only the temple at Arad in the list of excavated Israelite temples (e.g., Ottosson 1980, p. 108; see also Fritz 1995, p. 147; Wright 1985, pp. 214, 252; Dever 2005, p. 170). The scarcity of temples is also expressed, indirectly, by Gabriel Barkay (1992) in his chapter on the Iron Age II in The Archaeology of Ancient Israel (Ben-Tor 1992); although this is the largest chapter in the book (and rightly so, given the large exposure of levels from this period), it does not even include a section or heading on temples and cultic structures, in stark contrast to chapters on earlier epochs (for example, Gonen 1992b, pp. 222-32; Kempinski 1992, pp. 174-75, 196-97).

Many of the above-quoted scholars who discussed Israelite religion(s) were of course aware of the paucity of the evidence, and Dever (2005, p. 170) explicitly wrote that "(T)he only known full-fledged Israelite temple of the monarchic period is the one excavated at Arad [ . . . ]" (see also Dever 1983, p. 573). And Zevit admitted (Zevit 2001, p. 124) “(B)y quirk of fate, the clearest incontrovertible examples of cult sites relative to the religion of Israelites come from excavations at sites belonging to Israel's Iron Age neighbors [ . .. ]“ (see also Wright 1985, pp. 248-249; Fritz 1995, p. 145).

It is important to note we are not suggesting that the temples at Arad and perhaps Moza (along with the probable one at Dan) were the only cultic building(s) that existed in Iron Age II Israel and Judah - it is quite clear that there was one in Jerusalem, for example, and one can assume that there were a few more (either of the few mentioned by name in the Bible, like Bethel, or some that were not mentioned) which were not yet discovered-but the evidence suggests that such buildings were a rare phenomenon, much rarer than in the Bronze Age or in the surrounding Iron Age polities. While a more quantitative assessment will be presented below, I would first like to review the detailed information 
available from a series of urban and rural settings in the kingdoms of Israel and Judah, in order to demonstrate that should temples be prevalent, they were indeed expected to be found.

\subsection{Urban Iron Age II Israelite Settlement}

Iron II levels were exposed in dozens of sites in the Kingdoms of Israel and Judah, sometimes extensively so. Still, as noted above, practically no temples were found in archaeological excavations in these settings. For example, the site at Beth-Shemesh was excavated almost entirely by three expeditions (Bunimovitz and Lederman 2009; and additional references), but no temple was found. At Tell en-Nasbeh (biblical Mizpah), too, almost the entire Iron Age II city was exposed (Zorn 1993a, 1993b; and references; Figure 3), but no temples were found. The situation in Tell Beit-Mirsim is similar (Albright 1943, 1993; although its exposure was less massive). Large areas were excavated also in Beersheba (e.g., Herzog and Singer-Avitz 2016), but despite the search, no such temple was found (a dismantled horned altar was discovered, but no cultic building, and contrary to some assumptions, an altar did not have to belong to a temple). It should be noted that the excavation of Iron II levels at other sites-e.g., Megiddo, Hazor, and Tell el-Fara'h (N)—also greatly exceed most of the Late Bronze Age settlements, but no Iron II cultic buildings were unearthed there too. The contrast with the scarcely excavated Late Bronze Age towns is clear.

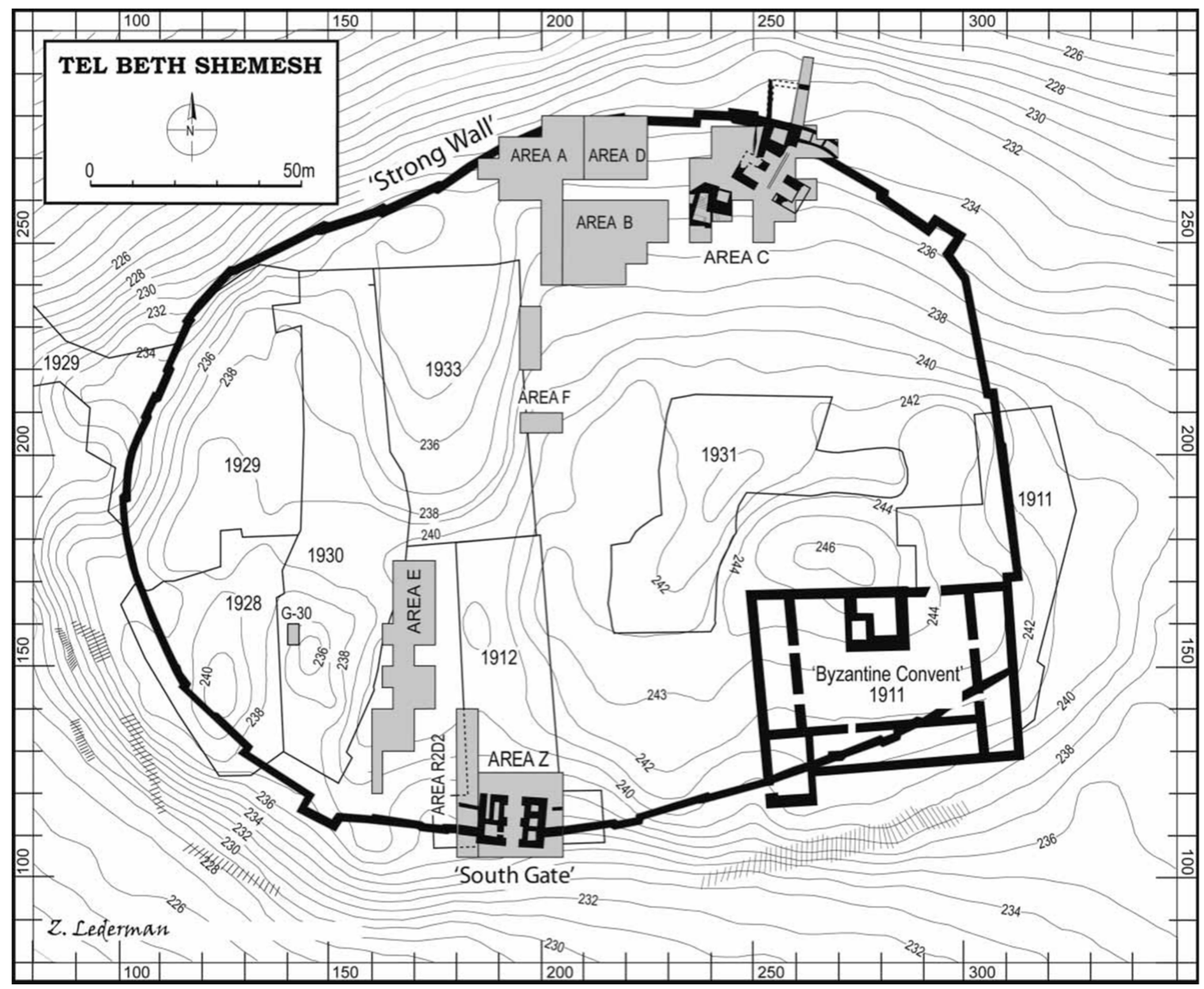

Figure 3. A plan of the mound of Tel Beth-Shemesh, with excavation areas marked. Despite the wide exposure of Iron II levels (in practice, all excavation areas, noted on the plan), no temples were uncovered (Bunimovitz and Lederman 2013, p. 7; courtesy of the Tel Beth-Shemesh excavations expedition). 


\subsection{Rural Temples and Israelite Settlements}

A number of Israelite Iron II villages were also widely exposed (e.g., Faust 2000), especially at Kh. Jemein (Dar 1986; Figure 4) and Beit Arye (Riklin 1997) that were excavated in their entirety, as well as Kh. Jarish (Amit 1989-1990), and others. Still, despite the fact that this exposure was larger than that of the Bronze Age villages described above, and notwithstanding the eagerness of archaeologists to find evidence for Israelite cult, no temples were found. The contrast with the Middle Bronze Age villages described above is striking.

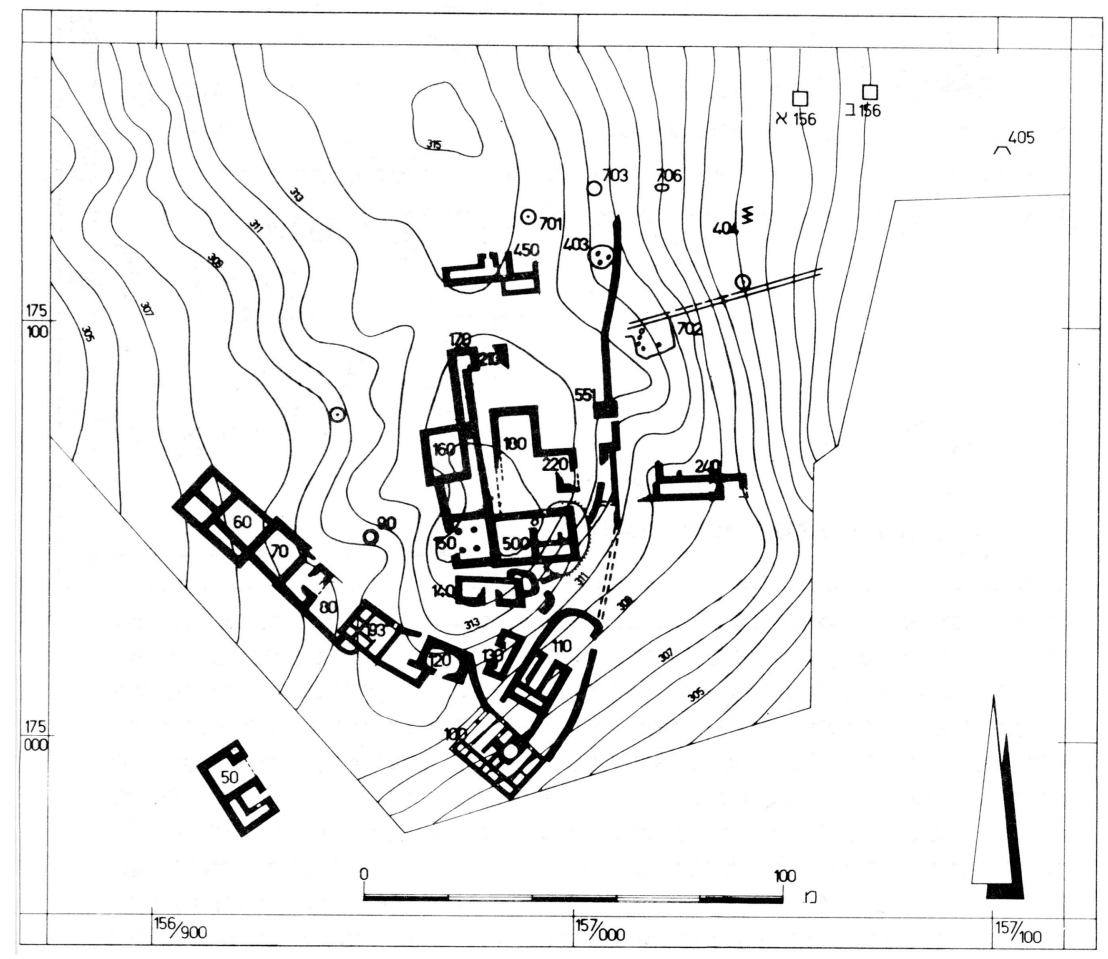

Figure 4. A plan of Kh. Jemein. Most of this Iron Age village was excavated, but no temple was unearthed (courtesy of Shimon Dar).

\subsection{The Fate of Older Canaanite Temples in Israelite Controlled Areas}

An additional evidence for the scarcity of temples in the kingdoms of Israel and Judah comes from the fate of existing Iron I Canaanite temples once they were incorporated within Israelite territories. Indeed, the transformation in the function of locales which for centuries served for sacred purposes is most revealing. Ottosson (1980, p. 106), for example, writes, “(A)t sites such as Megiddo, Hazor, and Shechem, where clearly delimited temple areas could be excavated, however, the cultic tradition vanishes completely during the Iron Age" (see also Halpern 2000, p. 559). At Megiddo the change is most noticeable, and with the destruction of Megiddo VI in the early 10th century, the millennia long cultic tradition came to an end, and no temple stood any more in what used to be Megiddo's sacred precinct. At Shechem, the Canaanite Fortress Temple (strata XVI-XV), was destroyed already at some point during the Iron Age I and never rebuilt in the later, probably Israelite phases (Stager 1999, and references). At Hazor, too, although the Late Bronze Age city boasted a number of temples (above), no temples were unearthed in the small Iron II city that was built in the 10th century BCE. Even more striking is the fact that the area of one the Canaanite cultic complex, located within the smaller Iron Age city, was left as an unbuilt, empty area-as Sandhaus (2013, p. 111) wrote: “The Israelite city developed around these ruins and always avoided building on top of them, possibly as a result of some sort of building ban on this location." Cessation in cultic activity in the Iron II can also be seen in Tel Qasile and Beth-Shean. In the former, the temple area grew and developed in the course of strata 
XII-X, but only scant remains were found after the stratum $\mathrm{X}$ temple was devastated, indicating at most some ephemeral use in the area after it was most likely incorporated with the Israelite polity (for the scanty remains, see Mazar 1980, pp. 50-53; 2009b, p. 327). And at Beth-Shean (according to Mazar's interpretation, e.g., Mazar 2006, pp. 34-35; 2009a, pp. 27-28), too, the earlier temples ceased to exist in the Iron Age IIA, apparently when the site was incorporated within the Israelite state.

Clearly, other than at Arad, probably Moza, and perhaps also Dan (along with Jerusalem, which is known from literary sources ${ }^{7}$ ), no temples are known from Iron Age II Israel and Judah. Given the contextual data from other epochs or polities this is striking, and in the following section we will attempt to show how extreme the rarity of temples in Israel and Judah is.

\section{Israelite Temples in Context: A Quantified Analysis}

Since, as we have seen above, Iron Age II levels were exposed to a much greater extent than those of the Late Bronze Age, if Iron II temples were as prevalent as those of the Late Bronze Age, then many dozens of Iron II temples should have been found.

This is a result of a number of factors (presented at length in Faust 2010; see also Faust and Safrai 2015, and therefore only presented briefly here).

First, the Iron II was a much more densely populated period, with a much higher population than the Late Bronze Age; common estimates are in the scale of 8:1..$^{8}$ Although the numbers can be contested, the general trends are safe (as the various studies used the same methods and coefficients). ${ }^{9}$

The difference can be seen not only in the estimated population, but also in the number of excavated sites. The New Encyclopedia of Archaeological Excavations in the Holy Land (NEAEHL; Stern 1993) and the salvage excavations databases (e.g., Faust and Safrai 2005, 2015) serve as a general guide (the latter covers only Cisjordan, and while the former includes also a few sites in Transjordan, those were not counted). ${ }^{10}$ The number of sites in the NEAEHL (which is biased toward large sites and mounds) in which settlement remains from the Late Bronze Age were found is only 87, while the number of the Iron II settlements is 158 . When the salvage excavations database (biased toward small, rural sites) is examined, the difference is even larger. While only 45 Late Bronze Age settlement sites might be inferred, the number of the Iron II sites is $136 .{ }^{11}$ The above shows that the Iron II was far more populated than the Late Bronze Age, and that sites from the Iron Age II were excavated to a much larger extent than those of the Late Bronze Age. Hence, more remains of all types (including cultic buildings) are expected to have been found in those Iron II levels, should they have been present there in the same frequency.

Furthermore, the above reveals only part of the gap between the two periods, since it takes into account only the number of sites and not the extent of exposure of the different strata. Many Iron II levels, which are typically the upper levels in most ancient mounds, were exposed to a large extent (as noted above), while no Late Bronze Age sites were excavated to such a degree. And since the former were usually also larger, this means that the actual difference in exposure is much larger than that revealed by looking only at the number of sites.

7 And apparently a few other temples that are attested in the Bible.

8 Cf., Broshi and Finkelstein (1992) estimate of some 400,000 peoples for the Iron II, with Dever's (2003, p. 98) and Stager's (1998) estimate of some 50,000 for the Late Bronze Age. Other scholars suggested slightly lower (46,000 people according to Herzog 1999, p. 48) or higher (60,000 people according to (Broshi 1993a, p. 423); 60,000-70,000 people according to (Broshi 1993b, p. 14)) figures for the Late Bronze Age, but these differences are marginal compared with the gap with the Iron Age figures.

9 Notably, these figures compare the Late Bronze Age population with the entire population of the Iron II, and not only to the kingdoms of Israel and Judah. According to Broshi and Finkelstein (1992, p. 54), the latter's population was 332,500 (west of the Jordan River only), i.e., six to seven times larger than the estimated population of the entire country in the Late Bronze Age.

10 For extensive discussion of these sources of information, see Faust and Safrai 2015.

11 The vast majority of the excavations were carried out within the boundaries of the Iron Age II kingdoms of Israel and Judah. 
The number of Late Bronze Age versus Iron Age dwellings unearthed can serve as a good example of this gap. Gonen (1992b, p. 221), for example, had already noted the scarcity of excavated dwellings from the Late Bronze Age. Daviau scrutinized the evidence for excavated structures from the Late Bronze Age (Daviau 1993, pp. 219-436), and while she concluded that the data on many of the structures was insufficient for her purposes, her study gives an idea as to the number of complete structures that were exposed. A generous counting of complete houses will arrive at no more than 45 Late Bronze Age buildings throughout the country (including structures which Daviau did not study in detail due to the lack of data on the finds unearthed). Since the above was a generous estimate, it is safe to assume that enlarging the number to 50 Late Bronze Age dwellings will be the maximal figure possible. ${ }^{12}$

As far as the Iron Age II is concerned, however, well over $200^{13}$ Iron II dwellings were exposed in Israel and Judah. We believe that if the evidence will be thoroughly examined then the number will be larger, especially if the non-Israelites regions (e.g., the coast and the northern valleys) will also be taken into account. To err on the side of caution, let us compare the high figure of 50 Late Bronze Age dwellings, and the low estimate of 200 Iron II dwellings. If these figures are taken as a rough guide to the areas that were exposed in both periods, we should expect to find four times more Iron II finds than similar finds from the Late Bronze Age, should their relative frequency be similar. Therefore, if finds were random, we should expect Iron II temples to be more numerous at least by a factor of four than those of the Late Bronze Age. Since at least 20 Late Bronze Age temples were unearthed, then no less than some 80 Iron Age temples would have been found, if they were as frequent in this period as in the Late Bronze Age. Since this is not the case, and unequivocal Iron Age temples were found only at Arad, probably Moza, and perhaps also at Dan, it is clear that the finds are not random, and the difference is remarkable and requires an explanation.

The same is true when comparing the Iron Age II finds in Israel and Judah with their neighbors. Given the extensive exposure of so many sites in Judah and Israel, the absence of temples is striking, especially when compared to Philistia, Phoenicia, Moab, and other nearby regions (above). While the dearth of information from most regions makes a comparison very tricky, the situation in Philistia, where the number of excavations is known, enables it. Iron II temples were uncovered at Ekron and Gath (above). ${ }^{14}$ Two temples might seems a small figure, but when taking into account that only four Iron II sites which are clearly Philistine were excavated to any extent (in addition to Ekron and Gath, also Ashdod and Ashkelon), and that in all four only a small fraction of their area was exposed, then one must conclude that temples were common in Iron II Philistine sites. Given the above, it is likely that a few temples existed in every Philistine city. Hence, the contrast between the situation in non-Israelite sites (Philistine and others alike) and in the Israelite ones is striking.

\section{The Rarity of Israelite Temples: A Summary and an Update}

The survey of non-Israelite cultic structures in the Bronze and Iron Age puts the archeological finds in the Kingdoms of Israel and Judah in their proper context. The archaeological evidence discussed by previous studies on Israelite religion(s) might indeed relate to cult, but as far as cultic structures

12 The aim in "counting" the structures is not to arrive at an estimate of the number of Late Bronze Age buildings, nor at the total and exact number of the excavated dwellings. Rather, it is aimed to establish a basis of comparison between periods (below). If a few more houses were excavated after Daviau's book was published (or even if some structures were not discussed by her) is immaterial for our purposes, as this would not change the overall picture, especially as we exaggerate the number of Late Bronze Age structures in order to err on the side of caution.

13 Faust (2012, pp. 207-12), for example, mentioned some 120 complete houses, but this is only a partial list (originally compiled in 1997, for other purposes) of complete houses, and one could have added, even at the time the list was compiled, many dozens of additional structures at various sites. Thus, for example, Faust discussed only 26 structures at Tell en-Nasbeh (Faust 2012, pp. 72-77) whereas Zorn (1993b, pp. 116-20) analyzed more some 70 structures at this level most of which can be regarded as "complete." At Beth-Shemesh Faust discussed only three (3) structures, while dozens were exposed. A similar situation exists in additional sites, e.g., at Beersheba, Tell Beit Mirsim, and more, and hence 200 is a very conservative figure.

14 Note that some scholars suggested that a temple was found also at Ashdod and perhaps Yavneh (see above). 
(like Arad) are concerned, those are rare exceptions rather than the rule. As a whole, and despite the wide exposure, "real" temples are practically missing in the archaeological record of Iron Age II Israel and Judah. There was no "city temple," "village temple," or "neighborhood temple" in those polities, and there were no regional cultic centers spread across the landscape-at least not identifiable special buildings that were built for this purpose!

Clearly, the lack of cultic buildings is an important feature of Israelite religion. This stands in stark contrast to the way the Canaanite religions were practiced in the Bronze Age, and also to the religious practices in other Iron Age polities (and to some extent even by non-Israelites in the kingdoms of Israel and Judah; cf., Faust 2012, pp. 242-43), but appears to be a key to understanding Israelite religious practices.

I first published this conclusion in 2010, and while the initial publication did not draw much explicit discussion, it appears that the observation that Israelite temples were a rare phenomenon and that Israelite cult was mostly practiced in simpler settings is gradually getting wider attention, and is now accepted by various authorities who study Israelite religion. ${ }^{15}$ William Dever (2017, p. 503), for example noted recently that "For the majority of people, even in urban centers, religious beliefs and practices were focused on family rituals" (see also p. 497), and Carol Meyers (2017, p. 11), stated that "[ ... ] it should be emphasized that household rituals were the major and often only kind of ritual activity experienced by most Israelites. Large temple complexes were rare in ancient Israel, in contrast to surrounding areas." Zev Farber (2018, p. 441), in his recent overview of the religion of Judah in the 8th century BCE summarized that "In short, for the most part, Israelites and Judahites did not built temples." And Alpert Nakhai (2015, p. 93) noted that worship "was decentralised and locally-based, in contrast to the better-known components of worship, the formal temples that served the monarchy and other elites" (see also Houston 2013, p. 152; Ortiz 2018, p. 24). Clearly, the lack of built temples is a unique characteristic of Israelite religion, and this must be addressed and analyzed.

\section{Why Was the Pattern Not Identified}

If temples are indeed so rare, why was this pattern not identified a long time ago? While this question is only of secondary importance of course, it is still intriguing - how could such a clear pattern be missed?

It seems that a combination of factors led to the fact that the obvious pattern was not identified, at least not explicitly.

First of all, it appears as if biblical data and interpretations were influencing previous scholarship, and many scholars attempted to reconstruct a religion which was to a large extent expected on the basis of the interpretation of the texts. As noted, Israelite religion was a focus of intensive research, and hence prior knowledge influenced research questions and agendas; if to be more specific, scholars "knew" that the Israelite religion was practiced all over the country until Josiah's reforms, and therefore reconstructed such a religion (or religions). ${ }^{16}$ The following quote illustrates how biblical-driven conceptions shaped historical reconstructions, "(A)t the end of the monarchy in Judah the relationship between local and central sanctuaries was reversed. While in the pre-state period there were only local sanctuaries, and during the whole monarchical period both existed side by side, under Josiah at the end of the seventh century the local sanctuaries were closed and the cult was centralized in Jerusalem" (Kessler 2008, p. 89; see also Hagedorn 2005, p. 204; Vogt 2006, pp. 44, 46).

Since the existence of such "local" temples was simply assumed, and with the absence of sufficient "examples" from the Iron Age, scholarship drifted to two solutions to illustrate the cultic landscape of Israel and Judah until the time of Josiah:

15 I am not aware of any explicit attempt to challenge my argument, but many still follow the old consensus, for example (Schmitt 2014; Geller 2016, p. 312).

16 For the significance of Josiah's (and Hezekiah's) reforms in this context, see, e.g., (Albertz 1994; Vogt 2006); see also (Fritz 1995, p. 145; Borowski 2003, p. 24). 
(1) Scholars used the data about the distribution of Bronze Age Canaanite temples, assuming (usually implicitly) that it was similar, to reconstruct an Iron Age cultic landscape that is full with cultic buildings. ${ }^{17}$

(2) The few exceptional Iron Age cultic buildings in Israel and Judah were explicitly regarded as representative, and were used to complement the picture that was drawn on the basis of hypothesis derived from the Bible and, as noted above (\#1), on the cultic landscape of the Bronze Age (and that of other Iron Age polities) (e.g., Zevit 2001, p. 124; Dever 2005, p. 170; Geller 2016, p. 312; see also Wright 1985, pp. 248-49; Fritz 1995, p. 145, and see above).

While such an integrative methodology, which incorporates updated archaeological data with critical textual analysis, is usually the right approach, it has its risks. It appears that in this case, the biblical-driven expectations led (1) to a strong will to look for evidence for cult in general and cultic structures in particular (and it also encouraged the interpretation of finds as cultic, even when the evidence was dubious), and (2) to extrapolate from the finds, i.e., to use the data that was unearthed as an example of what must have been the reality elsewhere. This is of course the right procedure when the finds are representative, but this does not seem to be the case here, and the unique exceptions which required explanations were treated as representative examples of Israelite cult-places.

To this we can add another factor that contributed to the fact that this pattern was not addressed, and the influence of biblical scholarship and the situation in other Near Eastern societies of the Bronze and Iron Ages is exacerbated by the tendency of archaeologists to explain the evidence unearthed and, with a large degree of justification, to ignore "things" that were not found. As noted by Lamberg-Karlovsky (1985, p. 23), archaeologists are "burdened by their occupational hazard with a materialist bias." This is the reason why we (as archaeologists) usually tend to explain what there is, and ignore what there isn't. The study of Iron Age burials (to be discussed at some length below) can serve as another example. Hardly any Iron Age I (and early Iron Age II) burials were unearthed in Israel and Judah, but although this was "known" (e.g., Tappy 1995, pp. 65-66; Ilan 1997a, p. 385; 1997b, p. 220), the pattern was not systematically addressed until recently (Kletter 2002; Faust 2004). Studies of Iron Age burial practices concentrated (quite naturally) on the famous Judahite tombs of the late Iron Age and on the few tombs from the earlier phases of the period, and the "absence" of the finds during most of the period was not systematically dealt with. In this case, the few early tombs that were unearthed were discussed, and the degree of continuity between them and those of the preceding and succeeding periods was analyzed, but the most important element- that most of the population was not buried in such tombs-was usually not even mentioned until recently, let alone explained. It seems that after well over 100 years of extensive archaeological research in ancient Israel, we cannot ignore elements that were supposed to be found, but were not, and the absence or rarity of finds—-temples in this case-must be acknowledged. ${ }^{18}$

\section{Why Were Temples Not an Integral Part of Israelite Cult?}

Identifying the pattern, and noting that Israelites cult was not commonly practiced in temples, is the most important observation, and it has significant implications for the study of ancient Israelite religious practices.

This observations, however, naturally leads to two new questions: (1) why were temples not an integral part of Israelite cultic practices? and (2) how was Israelite cult practiced?

The second question will be dealt with in a separate article, and in the remainder of this paper I would like to offer an initial, even if probably only partial, answer to the first question: Why was Israelite cult practiced differently than other ancient Near Eastern religions?

17 In some cases, previous studies of Israelite religion(s) treated also Iron Age non-Israelite sites, and this added to the confusion.

18 For countering a possible claim that one cannot learn from the absence or rarity of such finds, see (Faust 2010, p. 30); see also (Stephens 2011). 
It appears that one possible answer is that this was probably a result of Israelite ethos and worldviews. For reasons to be recapitulated below, it was suggested by many that Israelite society had an ethos of "simplicity" and "egalitarianism", and that many overt signs of hierarchy and power were not viewed favorably. The existence of temples, and of temple personnel (i.e., official priests), transmit a clear message of hierarchy and social differentiation, and their lack (or rarity) is therefore suitable for a society that does not view signs of hierarchy positively. While it is possible that this ethos, evidence for whose existence will be presently discussed, is one of the causes for the scarcity of temples, it is important to emphasize that it is possible that other causes were perhaps directly related to Israelite religion religious practices. While a detailed discussion of Israelite religion is beyond the scope of this paper, it must be stressed that even if the rarity of temples had deeper, religious, causes, than the discussed ethos made this phenomenon socially acceptable, despite its being unique in the socio-cultural landscape of the ancient Near East.

\subsection{Israelite Ethos of Simplicity and Egalitarianism}

Many studies, on the basis of various considerations, textual and material alike, concluded that an ethos of egalitarianism and simplicity existed in Israelite society. Before focusing on the material evidence for this ethos, which is our main concern here, I should note that that many biblical scholars and historians, on the basis of various texts, claimed that Israelite society had such an ideology (e.g., Lods 1932; Wolf 1947; Albright 1961, p. 119; Mendenhall 1962; Kelso 1968, p. 48; Speiser 1971; Gordis 1971, pp. 45-60; Humphrey 1978; Gottwald 1979; Lenski 1980; Cross 1988; Berman 2008; Shapira 2009). ${ }^{19}$ While the texts are problematic sources, and each interpretation is met with counter-interpretations, the plethora of evidence for this ethos in so many biblical genres cannot be easily dismissed. Moreover, the ancient Israelites' material culture, which seems more straightforward, clearly support the existence of such an ethos. In the section below I would therefore like to present some of the material patterns that expose this ethos (for a more extensive discussion, see Faust forthcoming).

Before outlining the evidence, however, it must be stressed that we are not discussing an egalitarian society—such societies do not exist—but a society that has an ethos of egalitarianism. In such a society, many overt signs of hierarchy are not accepted, but others might be found, along with evidence for real stratification (see (Faust 2004, 2011, 2013), and many references; cf., (Parker Pearson 1982). Even pre-monarchic Israel had various form of leadership (like the elders), and this is clearly true for the stratified Iron II society, which had a full spectrum of hierarchy, from kings, though administrators, to the local elders (e.g., Reviv 1989; Faust 2012, and references). As we will see, the discussed ethos coexisted with actual stratification, and while not negating it, it did limited some expressions of hierarchy (while allowing others, cf., Stein 1994; Blanton 1998; Faust forthcoming).

\subsubsection{Lack of Royal Inscriptions}

A phenomenon that was acknowledged but only little discussed in the past is the lack of royal inscriptions in the kingdoms of Israel and Judah. We have noted that the territories of the kingdoms of Israel and Judah were excavated to a much larger extent than any other polity in the region, and have indeed yielded much larger quantities of finds of various sorts. Thus, Israel and Judah produced more ostraca than any other state in the region (e.g., Ahituv 1992). When one examines the quantity of royal inscriptions, however, the situation changes dramatically. Although not abundant in any polity, all polities in the region yielded such inscriptions (e.g., Gitin et al. 1997; Biran and Naveh 1993, 1995; McCarter 1996, pp. 84-96, and many others), with the exception of Israel and Judah (e.g., Na'aman 2002,

19 This ethos was seen as expressed in various biblical laws (like the law of the king, I Samuel 8: 7-18), passages and stories (like the story of Abimelech, Judges 9), and institutions (like the Edah; see Wolf 1947 for references). 
p. 94; Hallo 2003, pp. xxiii-xxvi; Rendsburg 2007). ${ }^{20}$ We are witnessing a strange pattern, in which the polities that were excavated much more intensively than all the others, and whose finds are much more numerous, are lacking royal inscriptions. ${ }^{21}$

This pattern cannot be an accident, as the large number of excavations indicates. I believe that in accordance with the other traits discussed in this section, the Israelite society did not generally approve of this genre (see also Stein 1994; Blanton 1998, p. 162 for a similar interpretation in a different context). ${ }^{22}$

\subsubsection{Tradition of Not Decorating Pottery}

It is well known that the Iron Age (both Iron I and II) highland pottery in particular, and the pottery in the kingdoms of Israel and Judah in general, was non-decorated (e.g., Dever 1995, p. 205; Mazar 1992b, p. 290; Bloch-Smith and Nakhai 1999, p. 76). ${ }^{23}$ While practiced already in the Iron Age I, this is much more noticeable in the Iron Age II, when many of the nearby polities/cultures did use decorated pottery, sometimes extensively (Faust 2006a, pp. 41-48; 2013). Decoration on pottery is used to convey messages of various sorts (David et al. 1988; Faust 2006a, with additional references), and the lack of any decoration is a very suitable channel not only of a message of difference from other societies, but also of egalitarianism and simplicity. Many scholars referenced the lack of decoration as a characteristic of Israelite pottery (e.g., Dever 1995, p. 205; Mazar 1992b, p. 290; Bloch-Smith and Nakhai 1999, p. 76), so the mere phenomenon does not need a detailed discussion, and I will exemplify it with Building 101 at Tel 'Eton. This residency, destroyed by the Assyrian army in the late 8th century BCE, was some $225 \mathrm{~m}^{2}$ large (on the ground floor), and ashlar stones were embedded in the structure's corners and doorways (e.g., Faust et al. 2017). The wealth of the inhabitants was expressed also in the finds within the structure, which included some 200 complete pottery vessels, including dozens of storage jars, many of which were discovered with their content, clearly indicating that large quantities of surpluses were stored in this large dwelling. Remains of cedar, imported from Lebanon, and the composition of the faunal assemblage, are also indicative of the inhabitant's wealth. Still, not a single vessel, out of some 200 pottery vessels uncovered in it, was decorated! This clearly exemplifies the phenomenon discussed here (and we will return to this example below).

What could be the explanation for the phenomenon? While a full discussion of style is beyond the scope of the present paper (e.g., Wiessner 1990; David et al. 1988; Faust 2002), suffice it here to refer, as an illuminative example, to an interesting parallel. A similar phenomenon of lack of decoration, though in a completely different time and place, was observed by Ivor Noel-Hume (1974, p. 108). He noticed that the earliest English delftware (in London) was usually elaborately decorated, but after the civil war potters began to produce undecorated plain vessels. Only after the restoration in 1660 did decorated pottery become popular again. Deetz (1996, p. 81) summarized this trend: "Puritan attitudes toward decoration of everyday objects might have had an effect on the delftware industry in the London area in the form of a reduction of the amount of decorated pottery before the Restoration." Deetz (1996, pp. 81-82), furthermore, attributes the lack of decoration on various artifacts in Anglo-America to Puritan attitudes. It seems to me that the situation in Iron Age Israel was

20 The Siloam Inscription does not mention the king, and cannot be regarded as royal in this sense.

21 Notably, other evidence for writing is found (like the above mentioned ostraca), so it cannot be claimed that illiteracy is the cause for the pattern.

22 Such inscriptions would probably be found in the future in some special circumstances, e.g., in non-Israelite regions of the kingdom of Israel or in palatial contexts (and rarely, perhaps even in Israelite cities or villages). The general pattern, however, seems substantial, and it is not likely to be affected by such (expected) future discoveries (cf., also Na'aman 2002, p. 94).

23 Slip and burnish are not regarded here as decoration. 
somewhat similar, and that we are witnessing a process in which an ethos, even if of a different type, is responsible for the 'simple' pottery and for the lack of decoration. ${ }^{24}$

\subsubsection{Avoidance of Imported Pottery}

Another well-known Israelite trait is the rarity of imported pottery (e.g., Dever 1995, p. 204; Bloch-Smith and Nakhai 1999, p. 76; Faust 2006a, 2006b, 2013). Obviously, this trait is much more significant in the Iron II, following the resumption of trade in the eastern Mediterranean, but is manifested in the Iron Age I by the almost total absence of Philistine pottery in the highlands. Indeed, imported pottery is extremely rare, and is often missing altogether, in Israelite sites, despite extensive evidence for trade in the very same sites (as was suggested in the past for various sites and regions, for example the Beersheba-Arad valleys in the seventh century BCE; Faust 2006a, pp. 49-64; 2006b; see also Lipschitz and Biger 1991). I will exemplify this phenomenon, again, with Building 101 at Tel 'Eton. Although cedars were discovered in the building, indicating wealth and participation in international trade, and despite additional evidence for wealth (above; see also Faust et al. 2017), not even one out of the nearly 200 complete pottery vessels unearthed in the building was imported. The rarity of imported pottery seems to reflect the same ethos of simplicity.

\subsubsection{The Lack (or Extreme Rarity) of Burials}

As already noted, hardly any Iron Age burials are known in the highlands prior to the 8th century BCE, an issue discussed at length by Kletter (2002) and myself (Faust 2004; see also Tappy 1995, pp. 65-66; Ilan 1997a, p. 385; 1997b, p. 220; Barkay 1994, p. 160, note 211; Dever 2003; Suriano 2018, pp. 59-60). This stands in sharp contrast to the Late Bronze Age in all parts of the country (highlands and lowlands; e.g., Gonen 1992a; Gonen 1992b, pp. 240-45), and to the Iron Age I in the lowlands (Bloch-Smith 1992; Kletter 2002; see also Lehmann and Varoner 2018). Tombs and burials could form an important channel for the transmission of messages of social difference and status, and they clearly served this purpose in the Late Bronze Age (e.g., Bunimovitz 1995, p. 326). While there was a variety of burials in Late Bronze Age Canaan, which could result from several reasons of which social hierarchy is but one, the Iron I lacks even the "multiple cave burials" that characterized the highland throughout most of the second millennium BCE (Gonen 1992b, p. 245), therefore breaking a continuity that prevailed through wide segments of Canaanite society for almost 800 years (Bunimovitz 1995, p. 331). Even if a few Iron I burials are identified in the highlands (Bloch-Smith 2004; see also Livingstone 2002), the general pattern is striking: during the Late Bronze Age the highlands were only sparsely settled but many tombs are known (Gonen 1992a; 1992b, p. 240-45; Eisenstadt et al. 2004; Peleg and Eisenstadt 2004; Peleg 2004), while during most of the Iron Age the area was filled with settlements, but such burials are practically absent (until the appearance of the Judahite tomb in the late 8th century BCE; Faust and Bunimovitz 2008, and many references). This means that in the kingdoms of Israel the tradition of burying only in simple inhumations prevailed until the destruction of the kingdom in the 8th century BCE. Notably, the egalitarian ethos was maintained even in the Judahite tomb, by the equal treatment accorded to all the dead (e.g., Barkay 1999, p. 97). ${ }^{25}$

Clearly, most individuals during this period were buried in simple inhumations (Faust 2004), but the lack of any observable burials is a clear reflection of an egalitarian ideology (not reality!), and exhibits a

24 Notably, this trait is very noticeable already in the Iron Age I, when it stands in contrast to the reality in the lowlands regions at the time (Faust 2006a), as well as to the situation during the closing phase of the Late Bronze Age (e.g., Franken and London 1995).

25 It is possible that the few similar tombs that were unearthed in the territories of the kingdom of Israel suggest that the tombs began to appear in the kingdom's last days, in tandem with the development of the Judahite tomb, only that the Assyrian conquests prevented its development and wider acceptance in this polity. It is more likely, however, that most such tombs in the territories of the kingdom of Israel are related to activities of Judahites in these territories during the period of Assyrian rule or even after its collapse. One way or the other, no such burials were apparently used in the kingdom of Israel during most of its existence. 
sharp contrast to Late Bronze Age Canaanite traditions. As burials have an important social role, they are a chief vehicle through which such an ideology can be expressed and channeled. ${ }^{26}$

\subsubsection{The Four-Room House}

As claimed elsewhere (Bunimovitz and Faust 2002, 2003; Faust and Bunimovitz 2003, 2014), an egalitarian ideology is reflected in the plan of the four-room house. This can be seen most clearly in an analysis of movement within this house. The four-room plan enables easy access to every room, and is lacking any hierarchy in the structuring of the rooms; unlike other dwellings (cf., Gilboa et al. 2014), there are hardly any movement restrictions, and once in the central room, one can go directly to the desired space. Again, this seems to reflect an ideology of egalitarianism.

\subsection{Israel's Ethos and Israelite Temples}

This is not the place to discuss any of these traits in details, as each of them deserves an article of its own (see also Faust 2004, 2006a, 2011; Faust and Bunimovitz 2014), but the important thing is that they all attest to the same phenomenon - that the Israelite population had an ideology of simplicity and egalitarianism (such accordance between various facets of culture is expected; see Deetz 1996; David et al. 1988, p. 378; Hodder and Hutson 2003). Thus, while society was stratified, the ideology influenced behavior in many ways that are reflected in the finds. No society is truly egalitarian, and the Israelite society was clearly not, especially during the Iron Age II (the period of the Monarchy). The ideology, however, influenced many traits, as we have seen here, and although reality was different and stratification can clearly be seen in many settlements (even if not in all, and see detailed discussion in Faust 2012), the ethos had a major influence on Israel's material culture and the extreme rarity of temples was possibly one of them. As noted above, it is possible that rarity of temples should also be examined within a more religious context, and while this question is beyond the scope of the present paper it is clear that the discussed ethos at least enabled the Israelite society accept the scarcity of temples, although it run counter to the practice in most other ancient Near Eastern societies.

While the ethos had earlier "origins" (Faust 2015), it was adopted as a major factor in Israel's self-identification in the Iron I, when society was fairly simple and the ethos was more in line with reality (although society was not egalitarian even at this time). Still, the ethos continued to be a dominant feature in Israel's self-perception also in the Iron II, and although society became more and more stratified, various material traits betray the existence of this ethos. The rarity of temples was just another reflection of this ideology, and we should attempt to understand the "local" reasons for the existence of each of the few temples that did exist, rather than assume that they are representatives. It is likely that the mere existence of this ethos made it easier, at a later stage, for society to accept the idea of a centralized cult. For our purpose, sufficient it is to note that it is likely that the ideology of egalitarianism and simplicity was one of the reasons for the scarcity of temples in Iron II Israel and Judah or, in the least, it allowed its wide-scale acceptance.

\section{Summary and Conclusions}

Temples have an important role in many periods and societies, and are therefore abundant in many cultures, dominating the cultural and even the built landscape of many regions. Still, despite the exposure of large areas-sometimes almost complete settlements-hardly any Iron II Israelite buildings devoted to cultic activity were unearthed by archaeologists.

Given the many excavations and the large exposure of Iron II settlements in Israel and Judah-exposure that greatly exceeds that of other periods and regions-this rarity seems to be

26 For examples where burials reflect an egalitarian ethos, although the society is highly stratified, see Metcalf and Huntington (1991, p. 134) regarding Saudi Arabia, and Parker Pearson (1982) regarding England. For a detailed discussion, see (Faust 2004); forthcoming, and references. 
a significant aspect of Israelite religion. No matter how the Israelites practiced their religion, the archaeological evidence suggests that it was not usually performed in temples or buildings erected for cultic purposes. The observation that in the kingdoms of Israel and Judah built temples were rare is an important step in understanding the religious practices within those polities.

It is possible that the causes for the rarity of temples are connected to the Israelite ethos of simplicity and egalitarianism and the associated worldviews. But even if other reasons are responsible for the phenomenon, the discussed ethos is at least responsible for the acceptance of this unique type of religious expression among the Israelites. This ideology is expressed in a variety of texts, as well as in the lack (or, in the likely event that such will be discovered, in the extreme rarity) of royal inscriptions, in the extreme rarity of decoration on pottery vessels, in the extreme rarity of imported pottery, in the spatial configuration of the four-room house, and more. It is not surprising that temples, whose mere existence contradict this ideology, are also extremely rare, in accordance with this ethos. One way or the other, we must acknowledge that unlike its neighbors, Israelite cult was only rarely practiced in temples. The next step should be to study the settings in which the cult was actually practiced, both within the household (a topic that does receive some scholarly attention) and outside of it.

Acknowledgments: I would like to thank the anonymous reviewers for their comments.

Conflicts of Interest: The author declares no conflict of interest.

\section{References}

Aharoni, Yohanan. 1975. Investigations at Lachish: The Sanctuary and the Residency (Lachish V). The Emery and Claire Yass Publications in Archaeology 4. Tel Aviv: Tel Aviv University.

Aharoni, Miriam. 1993. Arad, the Israelite Citadels. In The New Encyclopedia of Archaeological Excavations in the Holy Land. Edited by Ephraim Stern. New York: Simon and Schuster, vol. 1, pp. 82-87.

Ahituv, Shmuel. 1992. Handbook of Ancient Hebrew Inscriptions from the Period of the First Commonwealth and the Beginning of the Second Commonwealth. Jerusalem: Bialik Institute. (In Hebrew)

Akkermans, Peter M.M.G., and Glenn M. Schwartz. 2003. The Archaeology of Syria: From Complex Hunter-Gatherers to Early Urban Societies (ca. 16,000-300 BC). Cambridge: Cambridge University.

Albertz, Rainer. 1994. A History of Israelite Religion in the Old Testament Period: From the Beginnings to the End of the Monarchy. Louisville: Westminster John Knox Press, vol. 1.

Albertz, Rainer, and Rudiger Schmitt. 2012. Family and Household Religion in Ancient Israel and the Levant. Winona Lake: Eisenbrauns.

Albertz, Rainer, Beth Alpert Nakhai, Saul M. Olyan, and Rüdiger Schmitt, eds. 2014. Family and Household Religion: Toward a Synthesis of Old Testament Studies, Archaeology, Epigraphy, and Cultural Studies. Winona Lake: Eisenbrauns.

Albright, William F. 1943. The Excavation of Tell Beit Mirsim, III: The Iron Age. Annual of the American Schools of Oriental Research. New Haven: ASOR, pp. 21-22.

Albright, William F. 1961. The Archaeology of Palestine. Harmondsworth: Penguin.

Albright, William F. 1993. Beit Mirsim, Tell. In The New Encyclopedia of Archaeological Excavations in the Holy Land. Edited by Ephraim Stern. New York: Simon and Schuster, vol. 1, pp. 177-80.

Alpert Nakhai, Beth. 2001. Archaeology and the Religions of Canaan and Israel. ASOR Books 7. Boston: American Schools of Oriental Research.

Alpert Nakhai, Beth. 2015. Where to Worship? Religion in Iron II Israel and Judah, 90-101. In Defining the Sacred: Approaches to the Archaeology of Religion in the Near East. Edited by Nicola Lanery. Oxford: Oxbow.

Amit, David. 1989-1990. Khirbet Jarish. Excavations and Surveys in Israel 9: 157-58. (In Hebrew)

Bahat, Dan. 1975. Excavations at Giv'at Sharett Near Beth-Shemesh. Qadmoniot 30-31: 64-67. (In Hebrew)

Bahat, Dan. 1993. Beth-Shemesh, Givat Sharet. In The New Encyclopedia of Archaeological Excavations in the Holy Land. Edited by Ephraim Stern. New York: Simon and Schuster, vol. 1, pp. 54-253.

Barkay, Gabriel. 1992. The Iron Age II-III. In The Archaeology of Ancient Israel. Edited by Amnon Ben-Tor. New Haven: Yale University Press, pp. 302-73.

Barkay, Gabriel. 1994. Burial Caves and Burial Practices in Judah in the Iron Age. In Graves and Burial Practices in Israel in the Ancient Periods. Edited by Itamar Singer. Jerusalem: Yad Ben-Zvi, pp. 96-164. (In Hebrew) 
Barkay, Gabriel. 1999. Burial Caves and Dwellings in Judah during the Iron Age II: Sociological Aspects. In Material Culture, Society and Ideology: New Directions in the Archaeology of the Land of Israel. Edited by Avraham Faust, Aren. M. Maeir and Ramat Gan. Jerusalem: Yad Ben-Zvi, pp. 96-102. (In Hebrew)

Beit Arieh, Itzhaq. 1991. The Edomite Shrine at Horvat Qitmit in the Judean Negev: Preliminary Excavation Report. Tel Aviv 18: 93-116. [CrossRef]

Beit Arieh, Itzhaq. 1995. Horvat Qitmit: An Edomite Shrine in the Biblical Negev. The Emery and Claire Yass Publications in Archaeology 11. Tel Aviv: Tel Aviv University.

Ben-Tor, Amnon. 1992. The Archaeology of Ancient Israel. New Haven: Yale University Press.

Berman, Joshua A. 2008. Created Equals: How the Bible Broke with Ancient Political Thought. Oxford: Oxford University. Biran, Avraham. 1994. Biblical Dan. Jerusalem: Israel Exploration Society.

Biran, Avraham, and Joseph Naveh. 1993. An Aramaic Stele Fragment from Tel Dan. Israel Exploration Journal 43: 81-98.

Biran, Avraham, and Joseph Naveh. 1995. The Tel Dan Inscription: A New Fragment. Israel Exploration Journal 45: 1-18.

Blanton, Richard E. 1998. Beyond Centralization: Steps toward a Theory of Egalitarian Behavior. In Archaic Statesin Archaic States. Edited by Gary M. Feinman and Joyce Marcus. Santa Fe: Institute of Advanced Studies, pp. 135-72.

Bloch-Smith, Elizabeth. 1992. Judahite Burial Practices and Beliefs about the Dead. Sheffield: Sheffield Academic Press.

Bloch-Smith, Elizabeth. 2003. Israelite ethnicity in Iron I archaeology preserves what is remembered and what is forgotten in Israel's history. Journal of Biblical Literature 122: 401-25. [CrossRef]

Bloch-Smith, Elizabeth. 2004. Resurrecting the Iron I Dead. Israel Exploration Journal 54: 77-91.

Bloch-Smith, Elizabeth, and Beth Alpert Nakhai. 1999. A Landscape Comes to Life: The Iron I Period. Near Eastern Archaeology 62: 62-127. [CrossRef]

Borowski, Oded. 2003. Daily Life in Biblical Times. Atlanta: Society of Biblical Literature.

Broshi, Magen. 1993a. Methodology of Population Estimates: The Roman-Byzantine Period as Case Study. In Biblical Archaeology Today, 1990: Proceedings of the Second International Congress on Biblical Archaeology. Edited by Avraham Biran. Jerusalem: Israel Exploration Society, pp. 420-25.

Broshi, Magen. 1993b. The Population of Iron Age Palestine. In Biblical Archaeology Today, 1990: Pre-Congress Symposium: Population, Production and Power. Edited by Avraham Biran and Joseph Aviram. Jerusalem: Israel Exploration Society, pp. 1-14.

Broshi, Magen, and Israel Finkelstein. 1992. The Population of Palestine in Iron Age II. Bulletin of the American Schools of Oriental Research 287: 47-60. [CrossRef]

Bunimovitz, Shlomo. 1995. On the Edge of Empires-The Late Bronze Age (1500-1200 BCE). In The Archaeology of Society in the Holy Land. Edited by Thomas E. Levy. London: Leicester University Press, pp. 320-31.

Bunimovitz, Shlomo. 2019. The Late Bronze Age. In Introduction to the Archaeology of the Land of Israel from the Neolithic to Alexander's Conquests. Edited by Avraham Faust and Hayah Katz. Ra'anana: The Open University of Israel. (In Hebrew)

Bunimovitz, Shlomo, and Avraham Faust. 2002. Ideology in Stone: Understanding the Four Room House. Biblical Archaeology Review 28: 32-41, 59-60.

Bunimovitz, Shlomo, and Avraham Faust. 2003. Building Identity: The Four Room House and the Israelite Mind. In Symbiosis, Symbolism and the Power of the Past: Canaan, Ancient Israel and Their Neighbors from the Late Bronze Age through Roman Palestine. Edited by William G. Dever and Seymour Gitin. Winona Lake: Eisenbrauns, pp. 411-23.

Bunimovitz, Shlomo, and Zvi Lederman. 2009. The Archaeology of border communities: Renewed excavations at Tel Beth-Shemesh part I, the Iron Age. Near Eastern Archaeology 72: 114-42. [CrossRef]

Bunimovitz, Shlomo, and Zvi Lederman. 2013. Solving a Century-Old Puzzle: New Discoveries at the Middle Bronze Gate of Tel Beth-Shemesh. Palestine Exploration Quarterly 145: 6-24. [CrossRef]

Cohen, Rudolf, and Yigal Yisrael. 1995. The Iron Age Fortresses at En Haseva. Biblical Archaeologist 54: $223-35$. [CrossRef]

Cross, Frank M. 1988. Reuben, First-Born of Jacob. Zeitschrift für die alttestamentliche Wissenschaft 100: 46-65. [CrossRef]

Dagan, Amit, Maria Eniukhina, and Aren M. Maeir. 2018. Excavations in Area D of the Lower City: Philistine Cultic Remains and Other Finds. Near Eastern Archaeology 81: 28-33. [CrossRef] 
Dar, Shimon. 1986. Hirbet Jemein-A First Temple Village. In Western Samaria in Shomron Studies. Edited by Shimon Dar and Ze'ev Safrai. Tel Aviv: Hakibutz Hameuchad, pp. 13-73. (In Hebrew)

Daviau, P.M. Michèle. 1993. Houses and their Furnishings in Bronze Age Palestine: Domestic Activity Areas and Artefacts Distribution in the Middle and Late Bronze Age. JSOT/ASOR Monographs Series 8; Sheffield: Sheffield Academic.

Daviau, P.M. Michèle. 2006. Hirbet el-Mudēyine in its Landscape, Iron Age Towns, Forts, and Shrines. Zeitschrift des Deutschen Palästina-Vereins 122: 14-30.

Daviau, P.M. Michèle, and Margreet Steiner. 2000. A Moabite Sanctuary at Khirbat al-Mudayna. Bulletin of the American Schools of Oriental Research 320: 1-21. [CrossRef]

David, Nicholas, Judy Sterner, and Kodzo Gavua. 1988. Why Pots are Decorated. Current Anthropology 29: 365-89. [CrossRef]

Deetz, James. 1996. In Small Things Forgotten, An Archaeology of Early American Life. New York: Anchor.

Dever, William. G. 1983. Material Remains and the Cult in Ancient Israel: An Essay in Archaeological Systematics. In The Word of the Lord Shall Go Forth. Edited by Carol L. Meyers and Michael O'Connor. Winona Lake: Eisenbrauns, pp. 571-87.

Dever, William. G. 1995. Ceramics, Ethnicity, and the Questions of Israel's Origins. Biblical Archaeologists 58: 200-13. [CrossRef]

Dever, William. G. 2003. Who Were the Israelites and Where Did They Come From? Grand Rapids: Eerdmans.

Dever, William. G. 2005. Did God have a Wife? Archaeology and Folk Religion in Ancient Israel. Grand Rapids: Eerdmans.

Dever, William. G. 2017. Beyond the Texts: An Archaeological Portrait of Ancient Israel and Judah. Atlanta: SBL Press.

Dothan, Moshe. 1993. Ashdod. In The New Encyclopedia of Archaeological Excavations in the Holy Land. Edited by Ephraim Stern. New York: Simon and Schuster, vol. 1, pp. 93-102.

Dothan, Trude. 2003. The Aegean and the Orient: Cultic Interactions. In Symbiosis, Symbolism and the Power of the Past: Canaan, Ancient Israel and Their Neighbors from the Late Bronze Age through Roman Palestine. Edited by William. G. Dever and Seymour Gitin. Winona Lake: Eisenbrauns, pp. 189-213.

Edelstein, Gershon. 1993. Manahat_A Bronze Age Village in Southwestern Jerusalem. Qadmoniot 103-104: 92-102. (In Hebrew)

Eisenberg, Emanuel. 1976. The Temples at Tel Kittan. Qadmoniot 36: 105-9. (In Hebrew)

Eisenberg, Emanuel. 1993a. Nahal Rephaim-A Bronze Age Village in Southwestern Jerusalem. Qadmoniot 103-104: 82-91. (In Hebrew)

Eisenberg, Emanuel. 1993b. Kitan, Tel. In The New Encyclopedia of Archaeological Excavations in the Holy Land. Edited by Ephraim Stern. New York: Simon and Schuster, vol. 3, pp. 878-91.

Eisenstadt, Irina, Khaled Arabas, and Zur Ablas. 2004. A Late Bronze Age Burial Cave at Zawata. In Burial Caves and Sites in Judea and Samaria From the Bronze and Iron Ages (Judea and Samaria Publications 4). Staff Officer of Archaeology-Civil Administration of Judea and Samaria and Israel. Edited by Hananya Hizmi and Alon De-Groot. Jerusalem: Antiquities Authority, pp. 77-106.

Falconer, Steven. 1994. Early Village Life in the Jordan Valley: A Study of Rural, Social and Economic Complexity. In Archaeological Views from the Countryside, Village Communities in Early Complex Societies. Edited by Glenn M. Schwartz and Steven E. Falconer. Washington: Smithsonian Institution, pp. 121-42.

Falconer, Steven. 1995. Rural Responses to Early Urbanism: Bronze Age Household and Village Economy at Tell el-Hayyat, Jordan. Journal of Field Archaeology 22: 399-419.

Farber, Zev. 2018. Religion in Eighth-Century Judah: An Overview. In Archaeology and History of Eighth-Century Judah. Edited by Zev I. Farber and Jacob L. Wright. Atlanta: Society of Biblical Literature, pp. 431-53.

Faust, Avraham. 2000. The Rural Community in Ancient Israel during the Iron Age II. Bulleting of the American Schools of Oriental Research 317: 17-39. [CrossRef]

Faust, Avraham. 2002. Burnished Pottery and Gender Hierarchy in Iron Age Israelite Society. Journal of Mediterranean Archaeology 15: 53-73. [CrossRef]

Faust, Avraham. 2004. Mortuary Practices, Society and Ideology: The Lack of Iron Age I Burials in Highlands in Context. Israel Exploration Journal 54: 174-90.

Faust, Avraham. 2005. The Canaanite Village: Social Structure of Middle Bronze Age Rural Communities. Levant 37: 105-25. [CrossRef]

Faust, Avraham. 2006a. Israel's Ethnogenesis: Settlement, Interaction, Expansion and Resistance. London: Equinox.

Faust, Avraham. 2006b. Trade, Ideology and Boundary Maintenance in Iron Age Israelite Society. In A Holy Community. Edited by Marcel Purthuis and Joshua Schwartz. Leiden: Brill, pp. 17-35. 
Faust, Avraham. 2010. The Archaeology of the Israelite Cult: Questioning the Consensus. Bulletin of the American Schools of Oriental Research 360: 23-35. [CrossRef]

Faust, Avraham. 2011. How Were the Israelites Buried: The Lack of Iron Age I Burial Sites in the Highlands in Context. In The Highlands Depth: Ephraim Range and Binyamin. Edited by Aharon Tavger, Zohar Amar and Miriam Billig. Research Studies. pp. 12-32.

Faust, A. 2012. The Archaeology of Israelite Society in Iron Age II. Winona Lake: Eisenbrauns.

Faust, Avraham. 2013. Decoration versus Simplicity: Pottery and Ethnic Negotiations in Early Israel. Ars Judaica 9: 7-18.

Faust, Avraham. 2015. The Emergence of Iron Age Israel: On Origins and Habitus. In Israel's Exodus in Transdisciplinary Perspective: Text, Archeology, Culture and Geoscience. Edited by Thomas E. Levy, Thomas Schneider and William H. C. Propp. Cham: Springer, pp. 467-82.

Faust, Avraham, and Shlomo Bunimovitz. 2003. The Four Room House: Embodying Iron Age Israelite Society. Near Easter Archaeology 66: 22-33. [CrossRef]

Faust, Avraham, and Shlomo Bunimovitz. 2008. The Judahite Rock-Cut Tomb: Family Response at a Time of Change. Israel Exploration Journal 58: 150-70.

Faust, Avraham, and Shlomo Bunimovitz. 2014. The House and the World: The Israelite House as a Microcosm. In Family and Household Religion: Toward a Synthesis of Old Testament Studies, Archaeology, Epigraphy, and Cultural Studies. Edited by Rainer Albertz, Beth Alpert Nakhai, Saul M. Olyan and Ruediger Schmitt. Winona Lake: Eisenbrauns, pp. 143-64.

Faust, Avraham, and Ze'ev Safrai. 2005. Salvage excavations as a source for reconstructing settlement history in Ancient Israel. Palestine Exploration Quarterly 137: 139-58. [CrossRef]

Faust, Avraham, and Ze'ev Safrai. 2015. The Settlement History of Ancient Israel: A Quantitative Analysis. Ramat Gan: Rennert Center for Jerusalem Studies, Bar-Ilan University. (In Hebrew)

Faust, Avraham, Hayah Katz, Yair Sapir, Assaf Avraham, Ofer Marder, Guy Bar-Oz, Ehud Weiss, Chen Auman-Chazan, Anat Hartmann-Shenkman, Tehilah Sadiel, Oren Vilnay, Michael Tsesarsky, Pariente Sarah, Oren Ackermann, Natasha Timmer, Ofir Katz, Dafna Langgut, and Mordechay Benzaquen. 2017. The Birth, Life and Death of an Iron Age House at Tel 'Eton, Israel. Levant 49: 136-73. [CrossRef]

Faust, Avraham. Forthcoming. Between Reality and Ideology: Revisiting Israelite Ethos of Egalitarianism and Simplicity.

Flannery, Kent V. 1976. The Early Mesoamerican Village. New York: Academic Press.

Franken, Hank M., and Gloria London. 1995. Why Painted Pottery Disappeared at the End of the Second Millennium BCE. Biblical Archaeologist 58: 214-22. [CrossRef]

Fritz, Volkmar. 1995. The City in Ancient Israel. Biblical Seminar 29. Sheffield: Sheffield Academic.

Geller, Stephen A. 2016. Priests and Ritual. In The Wiley Blackwell Companion to Ancient Israel. Edited by Susan Niditch. Chichester: John Wiley, pp. 297-316.

Gilboa, Ayelet, Ilan Sharon, and Jeffrey R. Zorn. 2014. An Iron Age Canaanite/Phoenician courtyard house at Tel Dor: A comparative architectural and functional analysis. Bulletin of the American Schools of Oriental Research 372: 39-80. [CrossRef]

Gitin, Seymour. 2003. Israelite and Philistine Cult and the Archaeological Record in Iron Age II: The "Smoking" Gun Phenomenon. In Symbiosis, Symbolism and the Power of the Past: Canaan, Ancient Israel and Their Neighbors from the Late Bronze Age through Roman Palestine. Edited by William G. Dever and Seymour Gitin. Winona Lake: Eisenbrauns, pp. 279-95.

Gitin, Seymour, Trude Dothan, and Joseph Naveh. 1997. A Royal Dedicatory Inscription from Ekron. Israel Exploration Journal 47: 1-16.

Gonen, Rivka. 1992a. Burial Patterns and Cultural Diversity in Late Bronze Age Canaan. Winona Lake: Eisenbrauns. Gonen, Rivka. 1992b. The Late Bronze Age. In The Archaeology of Israel. Edited by Amnon Ben-Tor. New Haven: Yale University Press, pp. 211-57.

Gophna, Rivka. 1979. A Middle Bronze Age II Village in the Jordan Valley. Tel Aviv 6: 28-33. [CrossRef]

Gordis, Rivka. 1971. Primitive Democracy in Ancient Israel. In Poets, Prophets and Sages, Essays in Biblical Interpretation. Edited by Robert Gordis. Bloomington-London: Indiana University Press, pp. 45-60.

Gottwald, Norman K. 1979. The Tribes of Yahweh. New York: Orbis Books.

Hagedorn, Anselm C. 2005. Placing (a) God: Central Place Theory in Deuteronomy 12 and at Delphi. In Temple and Temple Worship in Biblical Israel. Edited by John Day. London and New York: T\&T Clark, pp. 188-211. 
Hallo, William W. 2003. Introduction: The Bible and the Monuments. In The Context of the Scripture. Edited by William W. Hallo and K. Lawson Younger. Volume Two: Monumental Inscriptions from the Biblical World. Leiden: Brill, pp. xxi-xxvi.

Halpern, Baruch. 2000. Centre and Sentry: Megiddo's Role in Transit, Administration and Trade. In Megiddo III, The Emery and Claire Yass Publications in Archaeology 11. Edited by Israel Finkelstein, David Ussishkin and Baruch Halpern. Tel Aviv: Tel Aviv University, pp. 535-77.

Haran, Menahem. 1981. Temples and Cultic Open Areas as Reflected in the Bible. In Temples and High Places in Biblical Times. Edited by Avraham Biran. Jerusalem: The Hebrew Union College, pp. 31-37.

Herr, Larry G., and Douglas R. Clark. 2009. From the Stone Age to the Middle Ages in Jordan: Digging Up Tall al-'Umayri. Near Eastern Archaeology 72: 68-97. [CrossRef]

Herzog, Ze'ev. 1997. The Arad Fortresses. In Arad. Edited by Ruth Amiran, Ornit Ilan, Michael Sebanne and Zeev Herzog. Tel-Aviv: Hakibbutz Hameuchad and the Israel Exploration Society, pp. 113-292. (In Hebrew)

Herzog, Ze'ev. 1999. The Canaanite City between Ideology and Archaeological Reality. In Material Culture, Society and Ideology: New Directions in the Archaeology of the Land of Israel. Edited by Avraham Faust and Avraham Maeir. Ramat Gan: Bar-Ilan University, pp. 42-50. (In Hebrew)

Herzog, Ze'ev, and Lily Singer-Avitz. 2016. Beer-Sheba III: The Early Iron IIA Enclosed Settlement and the Late Iron IIA-Iron IIB Cities. Tel Aviv: The Institute of Archaeology, Tel Aviv University.

Hess, Richard S. 2007. Israelite Religions: An Archaeological and Biblical Survey. Grand Rapids: Baker Academic.

Hodder, Ian, and Scott Hutson. 2003. Reading the Past, 3rd ed. Cambridge: Cambridge University.

Holladay, John S. 1987. Religion in Israel and Judah under the Monarchy: An Explicitly Archaeological Approach. In Ancient Israelite Religion: Essays in Honor of Frank Moore Cross. Edited by Patrick D. Miller, Paul D. Hanson and Samuel Dean McBride. Philadelphia: Fortress, pp. 249-99.

Houston, Walter J. 2013. Pentateuch (SCM Core Text). London: SCM.

Humphrey, Sarah C. 1978. Anthropology and the Greeks. London: Routledge and Kegan Paul.

Ilan, David. 1997a. Burial Sites. In Oxford Encyclopedia of Archaeology in the Near East 1. Edited by Eric Meyers. New York: Oxford University Press, pp. 384-86.

Ilan, David. 1997b. Tombs. In Oxford Encyclopedia of Archaeology in the Near East, 5th ed. Eric Meyers. New York: Oxford University Press, pp. 218-21.

Ji, Chang-Ho. 2012. The Early Iron Age II Temple at Hirbet Atarus and Its Architecture and Selected Cultic Objects. In Temple Building and Temple Cult Architecture and Cultic Paraphernalia of Temples in the Levant (2.- 1. Mill. B.C.E.), Proceedings of a Conference on the Occasion of the 50th Anniversary of the Institute of Biblical Archaeology at the University of Tübingen, Tübingen, Germany, 28-30 May 2010. Edited by Jens Kamlah. Wiesbaden: Harrassowitz, pp. 203-21.

Kelso, James L. 1968. The Excavations of Bethel (1934-1960). AASOR 39. Cambridge: ASOR.

Kempinski, Aharon. 1992. The Middle Bronze Age. In The Archaeology of Ancient Israel. Edited by Amnon Ben-Tor. New Haven: Yale University Press, pp. 159-210.

Kessler, Rainer. 2008. The Social History of Ancient Israel: An Introduction. Minneapolis: Fortress.

Kisilevitz, Shua. 2015. The Iron IIA Judahite Temple at Tel Moza. Tel Aviv 42: 147-64. [CrossRef]

Kletter, Raz. 2002. People without Burials? The Lack of Iron I Burials in the Central Highlands of Palestine. Israel Exploration Journal 52: 28-48.

Kletter, Raz, Irit Ziffer, and Wolfang Zwickel. 2010. Yavneh I: The Excavations of the 'Temple Hill' Repository Pit and the Cult Stands (OBO 30). Fribourg and Gottingen: Academic Press and Vandenhoeck and Ruprecht.

Kletter, Raz, Irit Ziffer, and Wolfang Zwickel. 2013. Yavenh II: The 'Temple Hill' Repository Pit (OBO 30). Fribourg and Gottingen: Academic Press and Vandenhoeck and Ruprecht.

Lamberg-Karlovsky, Clifford Charles. 1985. The Near Eastern 'Breakout' and the Mesopotamian Social Contract. Symbols 8: 8-11, 23-24.

Lehmann, Gunnar, and Oz Varoner. 2018. Early Iron Age Tombs in Northern Israel Revisited. Tel Aviv 45: $235-72$. [CrossRef]

Lenski, Gerhard. 1980. Review of N.K. Gottwald, The Tribes of Yahweh. Religious Studies Review 6: 275-78.

Levy, Thomas E. 2006. Archaeology, Anthropology and Cult: The Sanctuary at Gilat, Israel. London: Equinox.

Lipschitz, Nili, and Gideon Biger. 1991. Cedar of Lebanon (Cedrus Libani) in Israel during Antiquity. Israel Exploration Journal 41: 167-75. 
Livingstone, David. 2002. A Middle Bronze Age II and Iron Age I Tomb (No. 65) at Khirbet Nisya. Atiqot 43: 17-35.

Lods, Adolphe. 1932. Israel, from Its Beginning to the Middle of the Eighth Century. New York: A.A. Knauf.

Markoe, Glenn E. 2000. Phoenicians. Berkeley and Los Angeles: University of California.

Mazar, Amihai. 1980. Excavations at Tel Qasile, part one: The Philistine Sanctuary: Architecture and Cult Objects. Qedem 12. Jerusalem: The Institute of Archaeology, The Hebrew University of Jerusalem.

Mazar, Amihai. 1992a. Temples of the Middle and Late Bronze Age and the Iron Age. In The Architecture of Ancient Israel from the Prehistoric to the Persian Period. Edited by Aharon Kempinski and Hannah Katzenstein. Jerusalem: Israel Exploration Society, pp. 161-87.

Mazar, Amihai. 1992b. The Iron Age I. In The Archaeology of Israel. Edited by Amnon Ben-Tor. New Haven: Yale University Press, pp. 258-301.

Mazar, Amihai. 2006. Beth-Shean from the Late Bronze Age IIB to the Medieval Period. In Excavations at Beth-Shean 1989-96, Volume I: From the Late Bronze Age to the Medieval Period. Edited by Amihay Mazar. Jerusalem: IES and the Hebrew University of Jerusalem, pp. 26-47.

Mazar, Amihai. 2009a. Introduction and Overview. In Excavations at Beth-Shean 1989-96, Volume III: The 13th-11th Century BCE Strata in Areas N and S. Edited by Nava Panitz-Cohen and Amihay Mazar. Jerusalem: IES and the Hebrew University of Jerusalem, pp. 1-32.

Mazar, Amihai. 2009b. The Iron Age Dwellings at Tell Qasile. In Exploring the Longue Duree: Essays in Honor of Prof. Lawrence E. Stager. Edited by David Schloen. Winona Lake, Indiana: Eisenbrauns, pp. 319-36.

McCarter, P. Kyle. 1996. Ancient Inscriptions. Washington: Biblical Archaeology Society.

McNutt, Paula. 1999. Reconstructing the Society of Ancient Israel. Louisville: Westminster John Knox.

Mendenhall, George. 1962. The Hebrew Conquest of Palestine. The Biblical Archaeologist 25: 66-87. [CrossRef]

Metcalf, Peter, and Richard Huntington. 1991. Celebrations of Death, the Anthropology of Mortuary Ritual. Cambridge: Cambridge University Press.

Meyers, Carol. 2017. Contributing to Continuity: Women and Sacrifice in Ancient Israel. In Women, Religion, and the Gift: An Abundance of Riches (Sophia Studies in Cross-cultural Philosophy of Traditions and Cultures). Edited by Morny Joy. Cham: Springer, vol. 17, pp. 1-19.

Na'aman, Nadav. 2002. The Past that Shapes the Present: The Creation of Biblical Historiography in the Late First Temple Period and After the Downfall. Jerusalem: Yeriot.

Nahshoni, P. 2009a. A Philistine Temple in the Northwestern Negev. Qadmoniot 138: 88-92. (In Hebrew)

Nahshoni, Pirhiya. 2009b. Evidence for Cult in a Rural Shrine in the Northwestern Negev. Paper presented at a conference on Philistines in Southern Israel: New Studies, Ben-Gurion University, Beer-Sheva, January 14.

Niditch, Susan. 1997. Ancient Israelite Religion. New York and Oxford: Oxford University Press.

Noel-Hume, Ivor. 1974. A Guide to Artifacts of Colonial America. New York: Knopf.

Ortiz, Steven M. 2018. The United Monarchy. In Behind the Scenes of the Old Testament: Cultural, Social, and Historical Contexts. Edited by Jonathan S. Greer, John W. Hilber and John H. Walton. Grand Rapids: Baker Academic, pp. 208-15.

Ottosson, Magnus. 1980. Temples and Cult Places in Palestine. BOREAS: Uppsala Studies in Ancient Mediterranean and Near Eastern Civilizations, 12. Uppsala: Acta Universtatis Upsaliensis.

Parker Pearson, Michael. 1982. Mortuary Practices, Society and Ideology: An Ethnoarchaeological Case Study. In Symbolic and Structural Archaeology. Edited by Ian Hodder. Cambridge: Cambridge University Press, pp. 99-113.

Peleg, Yuval. 2004. Early Roman Farmhouse and Late Bronze Age Burial Cave East of Otniel. In Burial Caves and Sites in Judea and Samaria from the Bronze and Iron Ages (Judea and Samaria Publications 4). Edited by Hananya Hizmi and Alon De Groot. Jerusalem: Staff Officer of Archaeology—Civil Administration of Judea and Samaria and Israel Antiquities Authority, pp. 260-84.

Peleg, Yuval, and Irina Eisenstadt. 2004. A Late Bronze Age Tomb at Hebron (Tell Rumeideh). In Burial Caves and Sites in Judea and Samaria from the Bronze and Iron Ages (Judea and Samaria Publications 4). Edited by Hananya Hizmi and Alon De Groot. Jerusalem: Staff Officer of Archaeology-Civil Administration of Judea and Samaria and Israel Antiquities Authority, pp. 231-59.

Petit, Lucas, and Zeidan Kafafi. 2016. Beyond the River Jordan: A Late Iron Age Sanctuary at Tell Damiyah. Near Eastern Archaeology 79: 18-26. [CrossRef] 
Rendsburg, Gary. 2007. No Stelae, No Queens: Two Issues Concerning the Kings of Israel and Judah. In The Archaeology of Difference: Gender, Ethnicity, Class and the 'Other' in Antiquity. Edited by Douglas R. Edwards and C. Thomas McCollough. Boston: American Schools of Oriental Research, pp. 95-107.

Renfrew, Colin. 1985. The Archaeology of Cult: The Sanctuary at Phylakopi. London: British School at Athenes and Thames and Hudson.

Renfrew, Colin. 1994. The Archaeology of Religion. In The Ancient Mind: Elements of Cognitive Archaeology. Edited by Colin Renfrew and Ezra B.W. Zubrow. Cambridge: Cambridge University, pp. 47-54.

Renfrew, Colin, and Paul Bahn. 2012. Archaeology: Theories, Methods and Practice, 6th ed. London: Thames and Hudson.

Reviv, Hanoch. 1989. The Elders in Ancient Israel: A Study of a Biblical Institution. Jerusalem: Magnes.

Riklin, Shim'on. 1997. Bet Arye. Atiqot 32: 7-20. (In Hebrew)

Sandhaus, Débora. 2013. Hazor in the Ninth and Eighth Centuries B.C.E. Near Eastern Archaeology 76: 110-17. [CrossRef]

Schmitt, Rüdiger. 2014. A Typology of Iron Age Cult Places. In Family and Household Religion: Toward a Synthesis of Old Testament Studies, Archaeology, Epigraphy, and Cultural Studies. Edited by Rainer Albertz, Beth Alpert Nakhai, Saul M. Olyan and Rüdiger Schmitt. Winona Lake: Eisenbrauns, pp. 265-86.

Shapira, Amnon. 2009. Democratic Values in the Hebrew Bible. Tel-Aviv: Hakibbutz Hameuchad. (In Hebrew)

Smith, Mark S. 2002. The Early History of God: Yahweh and Other Deities in Ancient Israel. Grand Rapids and Cambridge: Eerdmans.

Speiser, Ephraim A. 1971. The Manner of the Kings. In The World History of the Jewish People. Edited by Benjamin Mazar. Jerusalem: Masada, vol. 3, pp. 280-287.

Stager, Lawrence E. 1998. Forging an Identity: the Emergence of Ancient Israel. In The Oxford History of the Biblical World. Edited by Michael David Coogan. New York: Oxford University, pp. 123-75.

Stager, Lawrence E. 1999. The Fortress-Temple at Shechem and the 'House of El, Lord of the Covenant. In Realia Dei: Essays in Archaeology and Biblical Interpretation in Honor of Edward F. Campbell, Jr., at His Retirement. Edited by Prescott H. Williams and Theodore Hiebert. Atlanta: Scholars Press, pp. 228-49.

Stein, Gil. 1994. Economy, Ritual and Power in 'Ubaid Mesopotamia. In Chiefdoms and Early States in the Near East: The Organizational Dynamics of Complexity. Edited by Gil Stein and Mitchell S. Rothman. Madison: Prehistory Press, pp. 35-46.

Stephens, Christopher. 2011. A Bayesian approach to absent evidence reasoning. Informal Logic 31: 46-65. [CrossRef]

Stern, Ephraim, ed. 1993. The New Encyclopedia of Archaeological Excavations in the Holy Land. Jerusalem: The Israel Exploration Society and Carta.

Suriano, Matthew. 2018. A History of Death in the Hebrew Bible. New York: Oxford University Press.

Tappy, Ron. 1995. Did the Dead Ever Die in Biblical Judah. Bulletin of the American Schools of Oriental Research 298: 59-68. [CrossRef]

Vogt, Peter T. 2006. Deutronomic Theology and the Significance of Torah: A Reappraisal. Winona Lake: Eisenbrauns.

Wiessner, Polly. 1990. Is there a Unity to Style? In The Uses of Style in Archaeology. Edited by Margaret Wright Conkey and Christine Ann Hastorf. Cambridge: Cambridge University Press, pp. 105-12.

Wolf, C. Umhau. 1947. Traces of Primitive Democracy in Ancient Israel. Journal of Near Eastern Studies 6: 98-108. [CrossRef]

Wright, George Ernest. 1978. A Characteristic North Israelite House in Archaeology. In the Levant: Essays for Kathleen Kenyon. Edited by Roger Moorey and Peter Parr. Warminster: Aris \& Phllips, pp. 54-149.

Wright, George R.H. 1985. Ancient building in South Syria and Palestine. Leiden: Brill.

Zevit, Ziony. 2001. The Religions of Ancient Israel: A Synthesis of Parallactic Approaches. London and New York: Continuum.

Zorn, Jeffrey. 1993a. Tell en- Nasbeh. In The New Encyclopedia of Archaeological Excavations in the Holy Land. Edited by Ephraim Stern. New York: Simon and Schuster, vol. 3, pp. 1098-102. 
Zorn, Jeffrey. 1993b. Tell en-Nasbeh: A Re-Evaluation of the Architecture and Stratigraphy of the Early Bronze Age, Iron Age and Later Periods. Unpublished Ph.D. dissertation. Berekely, CA, USA.

Zwickel, Wolfgang. 1994. Der Templkult in Kanaan und Israel (FAT 10). Tubingen: J.C.B Mohr (Paul Siebeck).

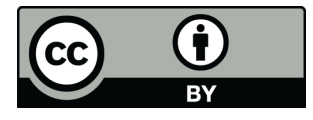

(c) 2019 by the author. Licensee MDPI, Basel, Switzerland. This article is an open access article distributed under the terms and conditions of the Creative Commons Attribution (CC BY) license (http://creativecommons.org/licenses/by/4.0/). 